Volume 2, Number 1, 2004, pp. 5 45

\title{
Leisure Port Development in the Incheon Area: Concepts and Benchmarks
}

\author{
Marc L. Miller" and Sung-Gwi Kim**
}

\begin{abstract}
In concert with an ambitious national agenda that emphasizes free trade and globalization, Incheon Metropolitan City is taking the first steps toward reinventing itself to become a twenty-first century "Pentaport" with integrated Seaport, Airport, Technoport, Business Port, and Leisure Port components. The Incheon Pentaport transformation-projected to be complete by 2020-will entail significant industrial, sociological, and institutional modification. Leisure Port objectives can be achieved through responsible planning attuned to the ideal of sustainable development and by empirical studies of Incheon tourism and leisure dynamics. International benchmarks of leisure port success are found in Sydney, Australia; Vancouver, Canada; and San Diego, USA, among seven other cosmopolitan cities. Growth estimations for coastal ferry passengers; beach use; recreational vessels and yachts in the Incheon region are encouraging. Incheon Leisure Port development of ten amenity destinations will require equal and multidisciplinary attention to questions of tourism design and tourism impacts. Important issues will concern environmental quality, clean shipping practices, the proper balance of modern and traditional amenities and attractions, trade-offs of cultural homogeneity and cultural diversity, and creative destination branding and marketing, among others.
\end{abstract}

Keywords: Incheon, Leisure, Leisure Port, Pentaport, Tourism, Sustainable Development.
"A world-economy always has an urban center of gravity, a city, as the logistic heart of its activity."

-- Fernand Braudel (1984: 27)

Butterflies come to pretty flowers. - Korean proverb

- Professor, School of Marine Affairs, University of Washington, Seattle, Washington, USA. E-mail: mlmiller@u.washington.edu

" Research Fellow, Korea Maritime Institute, Seoul, Korea. E-mail: sgkim@kmi.re.kr 


\section{INTRODUCTION}

At the beginning of the twenty-first century, Incheon Metropolitan City stands committed to playing a leading role in the implementation of national policy designed to position Korea as the premier hub of international commerce in Northeast Asia.'

Historically, Incheon has been important as a cultural center and as a major node in the global maritime shipping network. In 2001, the city began the modern augmentation of its international profile in explicit recognition of the logistic fact that 2 billion people - a figure approaching one-third of the world's population - reside within a 3.5 hour flight from Incheon (Urban Development Authority, 2003: 6). ${ }^{2}$

Over the last several years, Incheon International Airport has been created on reclaimed land to link Yeongjong Island and Yongyu Island. The facility-which opened 29 March 2001 with 2 runways, 1,267,000 $\mathrm{m}^{2}$ of passenger terminal, $129,000 \mathrm{~m}^{2}$ of cargo terminal, and 60 hardstands for aircraft-will be expanded in phases in order to accommodate 530,000 flights, 100 million passengers, and 7 million tons of cargo annually by 2020 (Urban Development Authority, 2003: 9). To further stimulate trade, the Korean government created a Customs Free Zone (CFZ) in Incheon (and also in Busan and Gwangyang) on 30 December 2002.

The airport construction and the CFZ represented the first steps in the reinvention of Incheon, a process that will entail dramatic industrial, sociological, and institutional change.

\section{PENTAPORT PROJECT ORIGINS}

\section{Incheon Pentaport}

The multifunctional diversification of Incheon into a "Pentaport" has been swift and incremental. For a short period beginning about 2000, Incheon envisioned itself as a "tri-port." With this template, the city planned a future that integrated an airport (Incheon International Airport), a seaport (Incheon International Port), and a teleport (Songdo Inpia) (see, Urban Development Authority, 2003).

Today, Incheon has refined its vision so that the city now aspires to rise as a twenty-first century integrated "Pentaport."

I Chang (2003: 452) reports that in 2002 President Kim Dae Jung first announced plans to position Korea as the Northeast Asia's Business Hub: "This plan is designed to develop Korea not only as a logistics hub but also as a banking and financial center and a production base for the region's multinational corporations."

${ }_{2}^{2}$ For more detail on how Incheon has been marketed as a tri-port, see 1) the "Welcome to Incheon Metropolitan City TRI-PORT" (2000 website: http://triport.inpia.net/english/ ) and the city website in which it is nested (2000 website: http://visit.inpia.net/ ), and also 2) "Tri-Port Incheon" (2003 website: http://incheon.kisc.org/servlet/KiscUK1USub01Q?OP=0\&MENU_ID=\%23IICS005\&SITE_ID=S005\&LAN G=2 ) linked to an earlier city site (1999/2000 website: http://incheon.kisc.org/). 
The pentaport concept sustains the conventional airport and seaport functions of the city, adds business port and technoport functions (a recasting of the teleport component of the tri-port), and-perhaps most importantly-emphasizes a leisure function. ${ }^{3}$ Thus, Incheon Pentaport is a logistic system composed of Incheon Seaport, Incheon Technoport, Incheon Airport, Incheon Business Port, and Incheon Leisure Port (see graphics of Park [2003] and Lee and Chang [2003] in Figures 1 and 2).

Figure 1. Incheon Pentaport

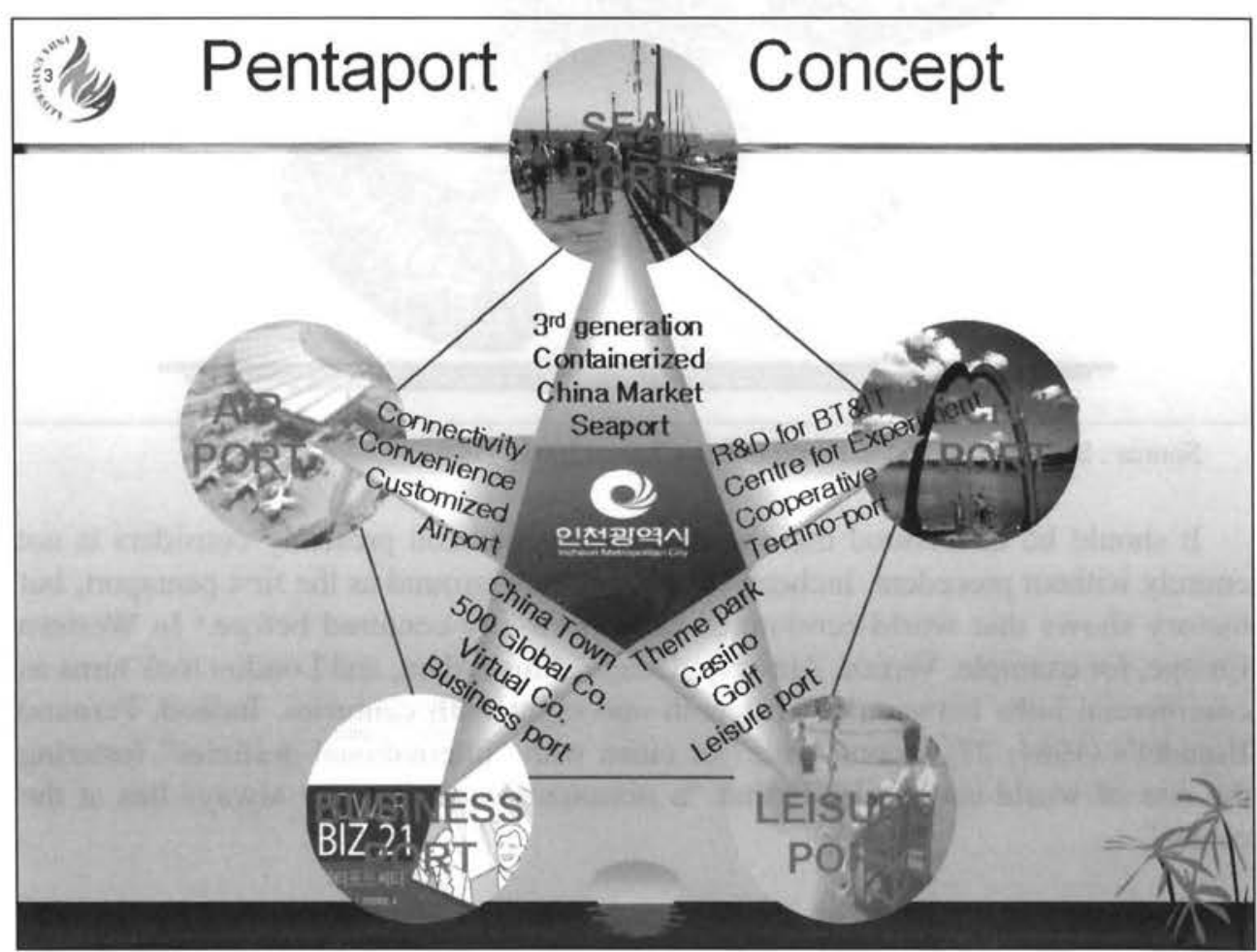

Source : Adapted from Prof. Kichan Park, "Networking Strategy of Pentaport Project," Pentaport Seminar to Develop Incheon as Logistics Hub in NEA, 27-28 October, 2003, Inha University, Incheon.

.$^{3}$ The pentaport concept may be traced to the vision of Dr. Seoung-Yong Hong, President of Inha University. President Hong first developed pentaport thinking when he crafted a long-term strategic plan for the Ministry of Maritime Affairs and Fisheries while serving as the Vice-Minister of the ministry. In 2000, the pentaport agenda for MOMAF was introduced in Ocean Korea 2. Incheon has benefited from recent international interaction of faculty at Inha University and the University of Washington. In particular, see Inha University (2003) and a special issue of Korean Observer (Volume 34, No. 3, 2003) for discussions of pentaport issues. 
Figure 2. Incheon Pentaport

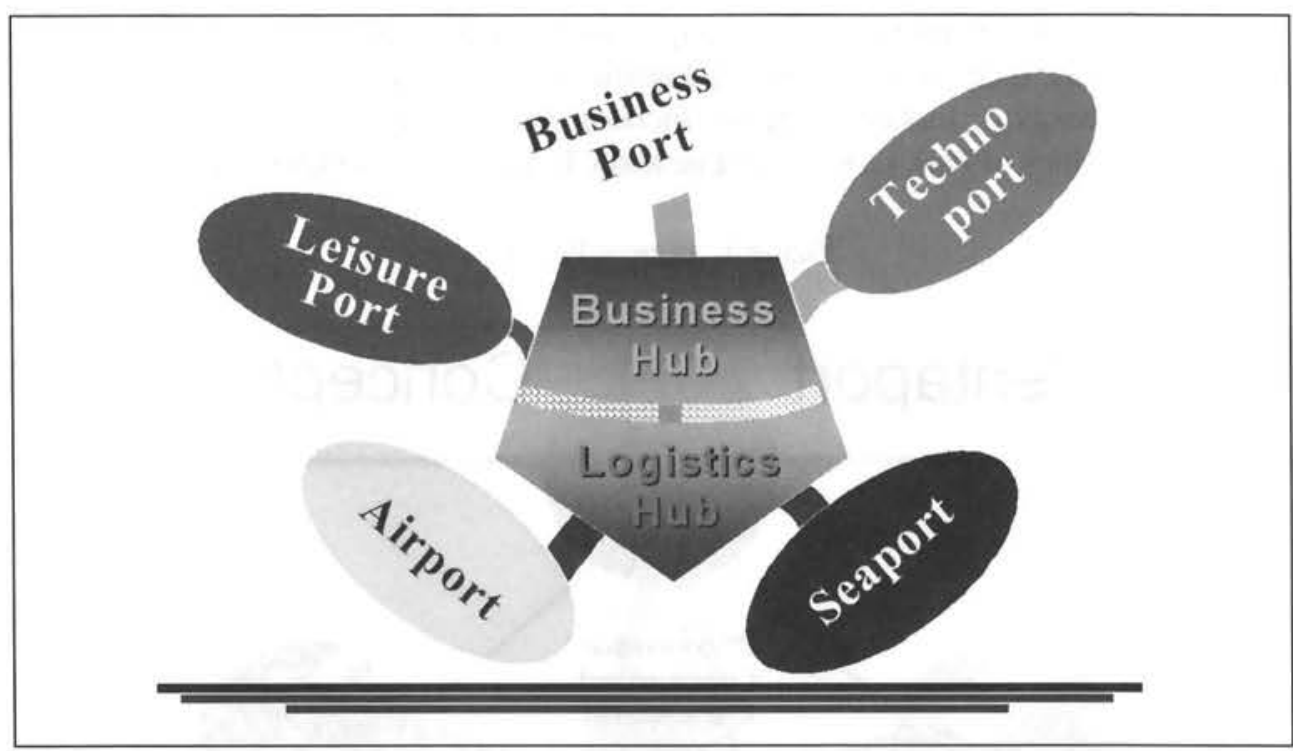

Source : Seung-Hee Lee [and reprinted in Chang (2003: 454)]

It should be understood that the change that Incheon presently considers is not entirely without precedent. Incheon is breaking new ground as the first pentaport, but history shows that world-economies have been city-centered before. ${ }^{4}$ In Western Europe, for example, Venice, Antwerp, Genoa, Amsterdam, and London took turns as commercial hubs between the fifteenth and eighteenth centuries. Indeed, Fernand Braudel's (1984: 27) second "rule" of cities with "international destinies" fostering the rise of world-economies is that "a dominant capitalist city always lies at the center."

\section{Incheon Leisure Port}

Whatever shape Incheon takes in the five-dimensional totality of its pentaport makeover, the future leisure landscape of Incheon is certain to be unique. To speak of the "Incheon Leisure Port" is to make reference to zones, pockets, and routes that facilitate tourism, recreation, sport, play, and other leisure-related activity that broadly fall within the jurisdiction of Incheon Metropolitan City. ${ }^{5}$

4 As Chang (2003: 454) has pointed out, other cities that may be viewed as multifunction ports include Singapore, Hong Kong, New York, London, Rotterdam, and Tokyo. Still, none of these has so explicitly developed a five-aspect growth strategy as has Incheon. For additional detail of how Incheon is cast as a pentaport, see the city's most current marketing effort "Penta-Port Incheon" (2003 website: http://www.incheon.go.kr/inpia/en/investment/vision/vision03.jsp ), the associated "Incheon Vision 21" (2003 website: http://www.incheon.go.kr/inpia/en/main.jsp ) and also the city's main website (20003 website: http://www.incheon.go.kr/).

s Of course, it is recognized that Incheon falls within the touristic and commercial hinterland of Seoul. 
As an Incheon Pentaport component, Incheon Leisure Port will function in a logistic manner to move people through the Northeast Asia hub while at the same time providing travelers and residents with a rich array of leisure-based services and products. In a manner of speaking, then, Incheon Leisure Port will develop as a leisure entrepôt-a transportation node and bona fide destination where people are matched with the leisure opportunities of their choice.

Writing of the seventeenth century capacity of Amsterdam for "collecting, storing, selling, and re-selling the goods of the universe," Braudel (1984: 236) has concluded "[w] hat was good for the entrepot trade, was good for Amsterdam." To the extent that Incheon pursues a similar agenda to shape leisure in its world-economy, ${ }^{6}$ it can be now be argued that what is good for the entrepôt trade is good for Incheon Leisure Port.

In passing, we pause to note that Incheon is simultaneously a port (in that it has historically depended on seaborne commerce) and a city. For ease of reading in this paper, we write of the transformation of Incheon into Incheon Pentaport, but it is perhaps more correct to say that the focus is the creation of a "penta-port/city hub" of Incheon.

Over the centuries, many cities have flourished because of seaborne trade, and have continued to develop their economies with airport development. However, as increasing industrialization and urbanization have characterized such metropolises, the city center rather than the airport or the seaport has rather remained the primary leisure destination as well as the hub of touristic exploration. To illustrate, business and other tourists do utilize Los Angeles International Airport, but they do so in order to gain access to the city and its hinterland. When one says he or she is "going to Los Angeles," it is generally understood that the airport is a means to an end and that activities will be conducted from a Los Angeles site that does not conjure an airport image.

In the case of Incheon, such an understanding may likely be revised. Incheon International Airport is part of an island complex and is connected to the city center by bridges. In the future, people who say they are "going to Incheon" will be signaling they will be visiting a pentaport (or, penta-port/city hub) that has as its center an airport nearly surrounded by a leisure zone.

\section{The Incheon Leisure Port Challenge}

Very simply, the Incheon Leisure Port challenge to which many Korean and international experts have been recruited is to create a leisure component of Incheon Pentaport that qualifies Incheon as a multifunction logistic hub in a world-economy.

- Following Braudel (1984: 22), we distinguish between two similar terminologies. We take "the world economy" to refer to the all human economic activity combined and examined as a single market. In contrast, "a world-economy" is a subset of the world economy: "A world-economy only concerns a fragment of the world, an economically autonomous section of the planet able to provide for most of its own needs, a section to which its internal links and exchanges give a certain organic unity." Incheon Pentaport, then, aspires to be the hub of the Northeast Asia world-economy. 
For this to occur, Incheon Leisure Port must be internally successful in its own right and must also be gracefully integrated with Incheon Seaport, Incheon Business Port, Incheon Technoport and Incheon Airport.

The Incheon Leisure Port challenge is presently being met with the activation of a comprehensive land-use/water-use Incheon Pentaport strategy. The overarching Pentaport Project process as described by one of the principal architects of the schedule, Kichan Park involves an integration of Pentaport scenarios, strategies, and action plans (see, Figure 3 ). ${ }^{7}$

Figure 3. Incheon Pentaport Project Process

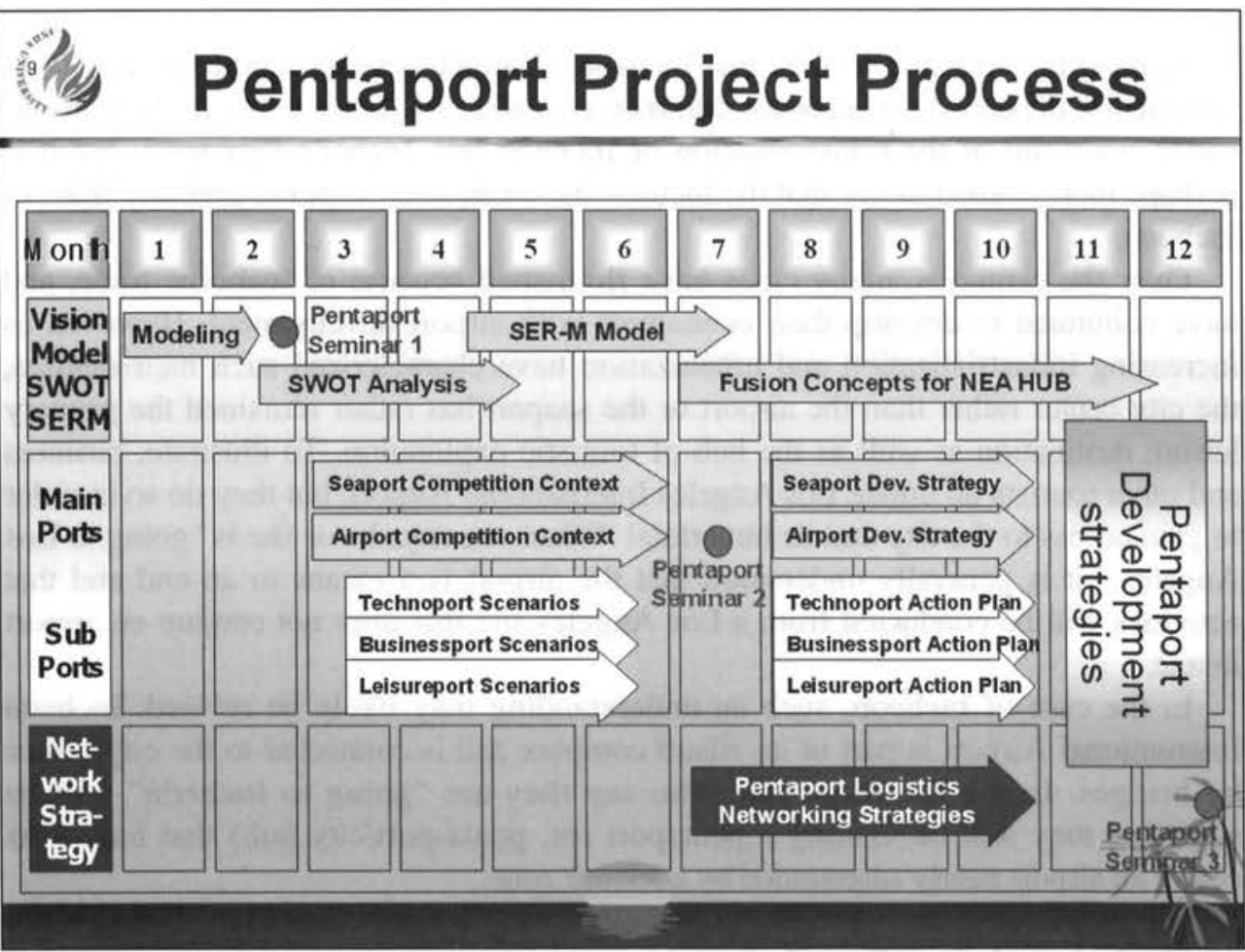

Source : Adapted from Prof. Kichan Park, "Networking Strategy of Pentaport Project." Pentaport Seminar to Develop Incheon as Logistics Hub in NEA, $27-28$ October, 2003, Inha University, Incheon.

7 We employ the term "Pentaport Project" to denote all research, planning, and development organized to fit the full Incheon Pentaport agenda. 
Fortunately, the Pentaport transformation has been facilitated by innovative government policy. In August 2003, the Korean government created three Incheon areas as the first Free Economic Zone (FEZ) components. This action was taken to advance the Pentaport agenda. As Jun (2003: 87) has pointed out:

The FEZ will exempt foreign investors from income and corporate taxes for the first three years of business operation, while in the following two years, they will be entitled to a 50 percent deduction form the normal tax rate. They will also be exempted from tariffs on imports.

The three FEZ areas (Figure 4) - each of which is destined to provide leisure port benefits-consist of:

- The Songdo Area encompassing 53 square kilometers of reclaimed land in southwest Incheon.

- The Yeongjong Area encompassing 138 square kilometers of reclaimed and island lands on which the Incheon International Airport is situated.

- The Cheongra Area encompassing 18 square kilometers of reclaimed land northwest of Incheon (Jun, 2003: 90-92).

Figure 4. Three Free Economic Zones

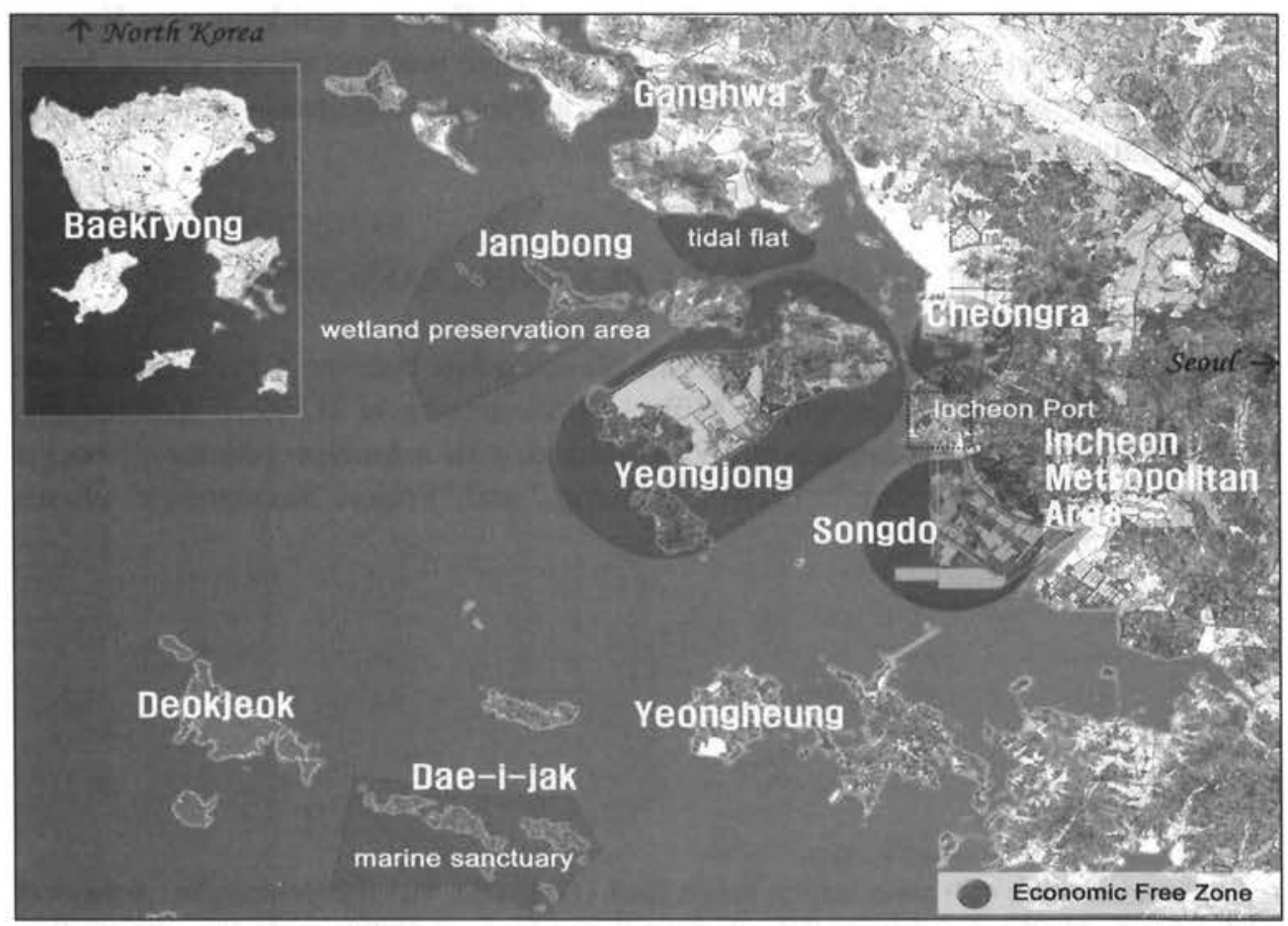


It is especially important to understand that the Pentaport Project concerns much more than economic development and also that non-economic factors are critically influential to its future. Braudel (1984: 623) points out that throughout world history capitalism has been shaped by "hierarchies of wealth, of state power, or of culture":

The worst error of all is to suppose that capitalism is simply an 'economic system,' whereas in fact it lives off the social order, standing almost on a footing with the state, whether as adversary or accomplice: it is and always has been a massive force, filling the horizon. Capitalism also benefits from all the support that culture provides for the solidity of the social edifice, for culture - though unequally distributed and shot through with contradictory currents-does in the end contribute the best of itself to propping up the existing order. And lastly capitalism can count on the dominant classes who, when they defend it, are defending themselves.

An equally important point to remember throughout the Pentaport Project is that it is a mistake to presume that the leisure pursuits in life-whether these take the form of recreation or tourism, involve family and friends or strangers, or are dramatic, contemplative, or aesthetic in nature-are necessarily subordinate to economic (as well as political and religious) endeavors. In many ways, the logistics of leisure provide meaning to human existence. And, as Sorensen (2003) has effectively argued, the quality of life and of leisure in Incheon-for Korean residents and Korean tourists, for international tourists, and for the expatriate business talent Incheon hopes to attract to provide symbolic-analytic services in Pentaport demand-must be highly regarded for Pentaport success. ${ }^{8}$

\section{LEISURE PORT PLANNING CONCEPTS}

Over the last several decades, tourism planning has become a professional and academic field of special expertise (Miller, 1989; Grenier, et al.1993). Accordingly, Incheon Leisure Port is appropriately actualized with a tourism planning process having "Front-end Planning," "Project Planning," and "Project Managemen" phases (see Figure 5).

8 Sorensen (2003: 464) points out that Robert Reich (1991: 177): "has argued that under conditions of globalization only those economies that can move from a focus on routine production services (i.e., manufacturing) and in-person production services (i.e., services that require direct customer interaction) to symbolic-analytic services - problem-solving, problem-identifying, and strategic-brokering services - will deliver high incomes and top prosperity. The symbolic-analytic services, however, are now dominated by the United States and, to a lesser extent, Europe." 
Figure 5. Toourism Planning Process

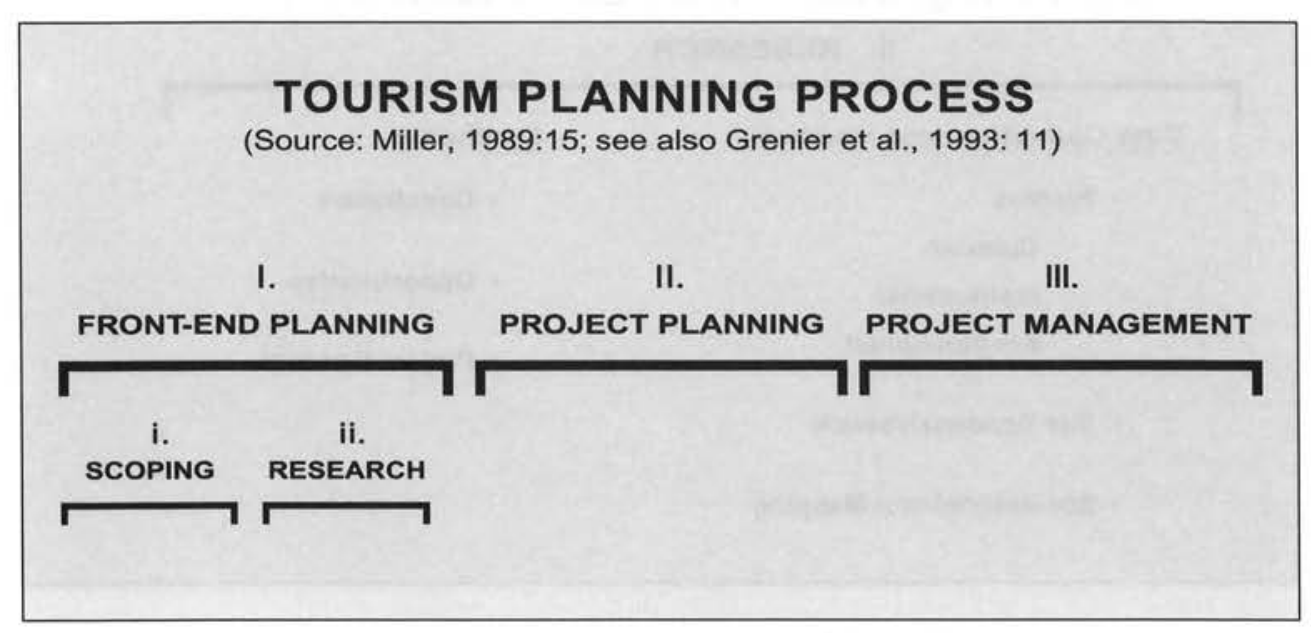

Figure 5-1. Toourism Planning Process (cont.)

Tourism Planning Process: 1. FRONT-END PLANNING (cont.)

i. SCOPING

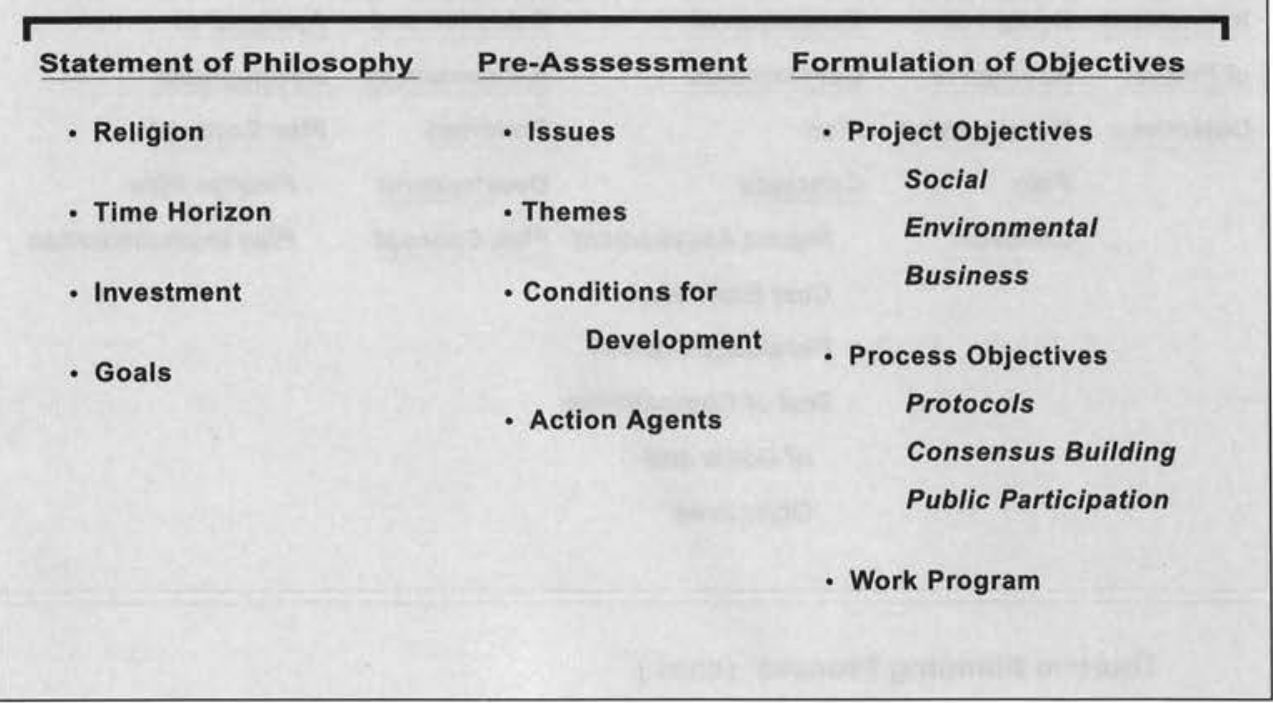


Tourism Planning Process: 1. FRONT-END PLANNING (cont.)

\section{ii. RESEARCH}

Data Collection and Analysis

- Profiles

Cultural

Institutional

Environmental

- Site Reconnaissance

- Eco-determinant Mapping

\section{Synthesis}

- Constraints

- Opportunities

- Project Concept

Figure 5-2. Toourism Planning Process (cont.)

Tourism Planning Process (cont.)

II. PROJECT PLANNING

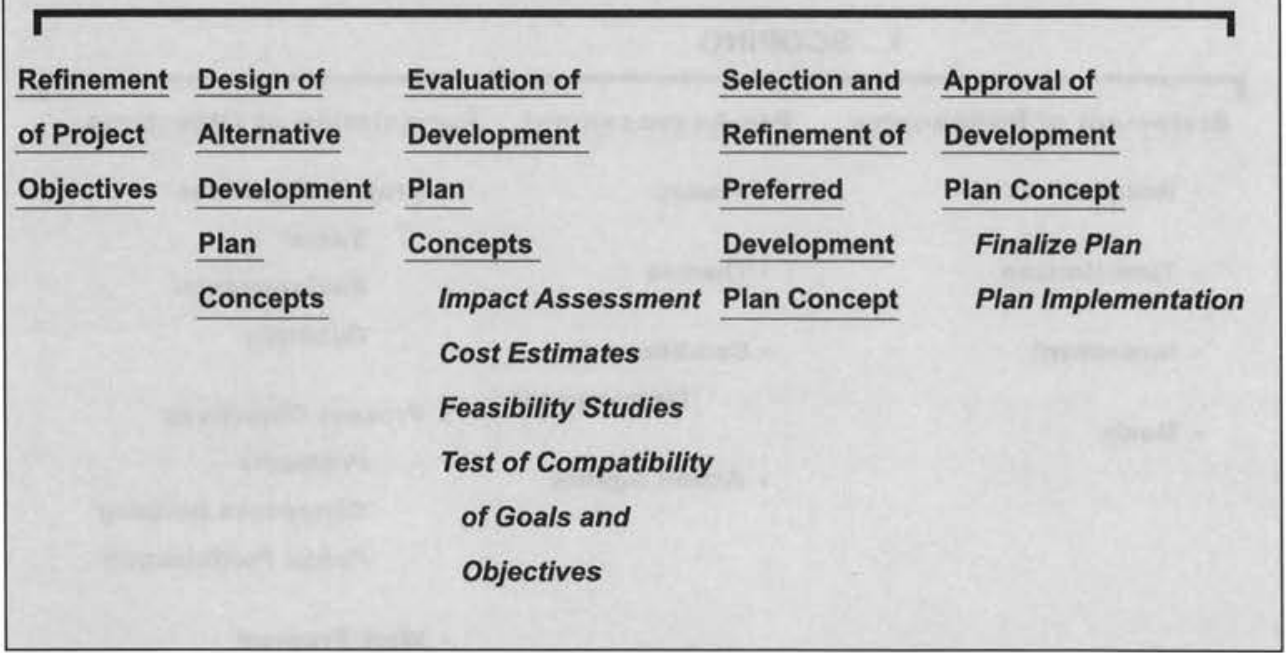

Tourism Planning Process (cont.)

III. PROJECT MANAGEMENT

$\Gamma$

Implementation Monitoring/Evaluation Refinement


Borrowing and extending from Miller and Ellis (2003a and 2003b; see also Miller and Auyong, 1991 and 1998, and Miller et al. 2002b), leisure and the coastal landscape concerns a tourism system of relationships among people, and a coastal tourism region.

- The Broker-Local-Tourist (BLT) System

Tourism systems (see Figure 6) may be sociologically treated as involving the interactions of 1) private sector, public sector and other tourism brokers, 2) resident locals who are not engaged in either the business or management of tourism, and 3) categories of tourists (Miller and Auyong, 1991:75) ${ }^{9}$

- The Coastal Tourism Region

Coastal tourism regions (see Figure 7) refer to the physical space in which tourism is conducted. Very generally, regions are characterized by a tourism zone containing an urban or industrialized core and special amenity destinations (cf, Miller and Ellis, 2003: 511-514).

Figure 6. Broker-Local-Tourist (BLT) Model of Tourism System

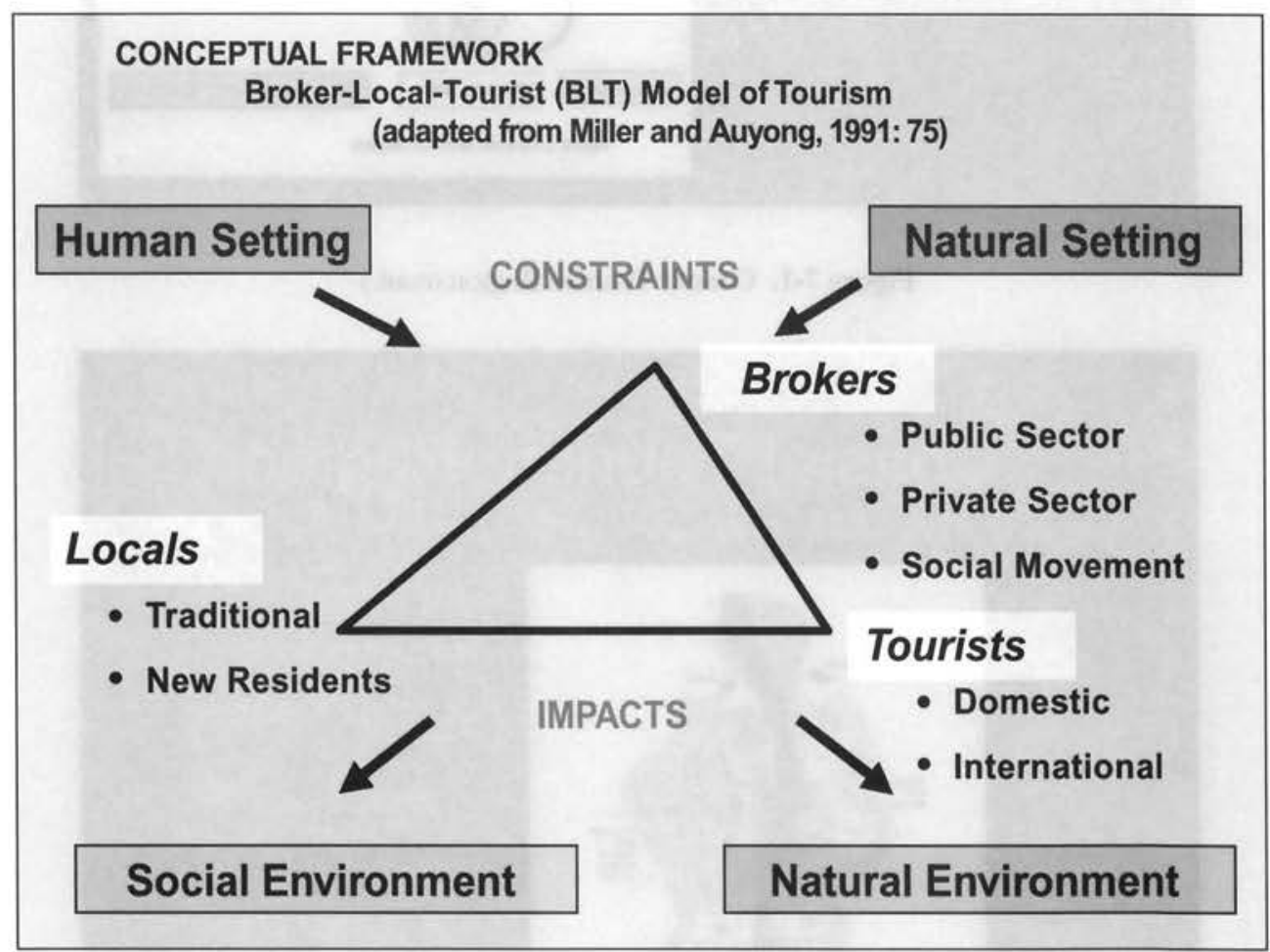

9 Coastal leisure concerns both the (recreational, educational, and business) activities of tourists and portions of the non-work activity of locals and brokers (see, Miller and Ditton, 1986: 11). Acknowledging, then, the importance of leisure of non-tourists, the terms "tourism" is for convenience taken to include the leisure behavior of visitors and residents. 
Figure 7. Coastal Tourism Region

\section{Coastal Tourism Region}

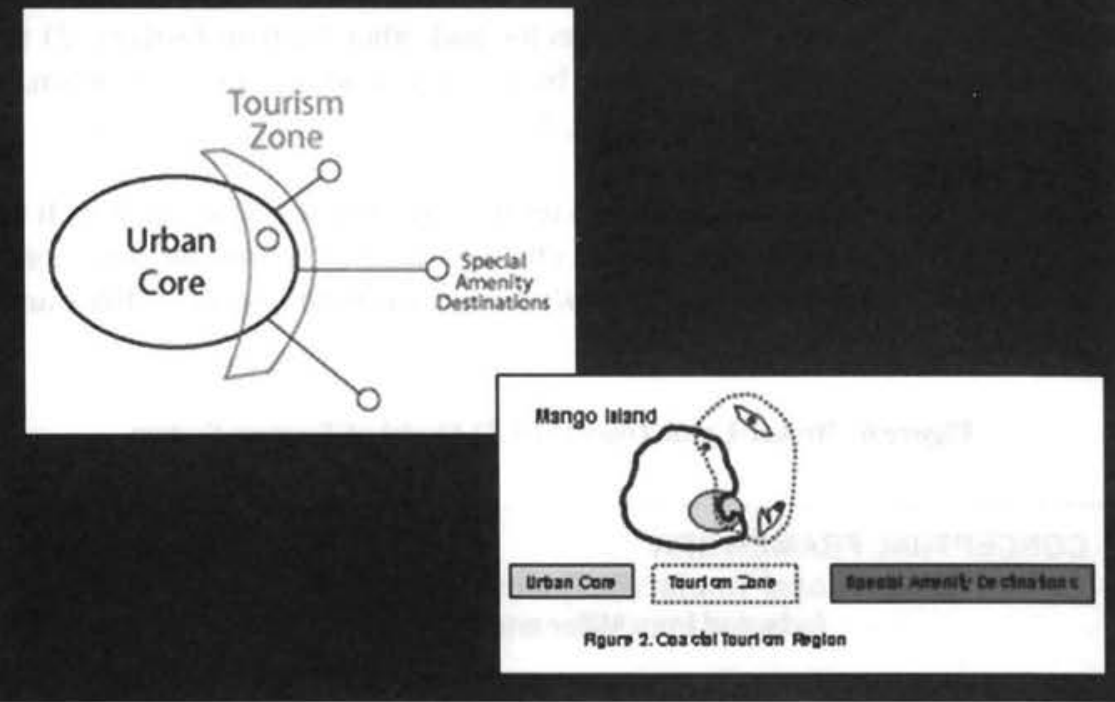

Figure 7-1. Coastal Tourism Region (cont.)

\section{Coastal Tourism Region}
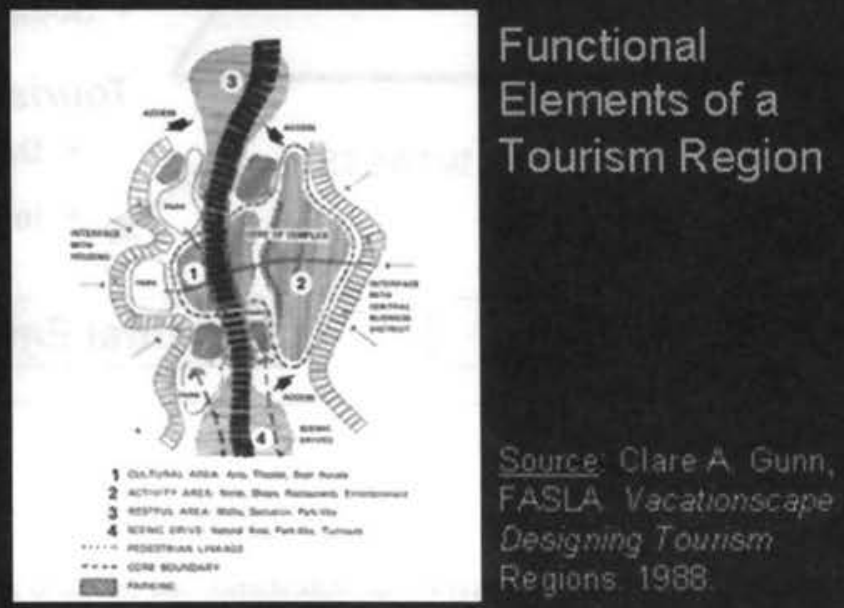


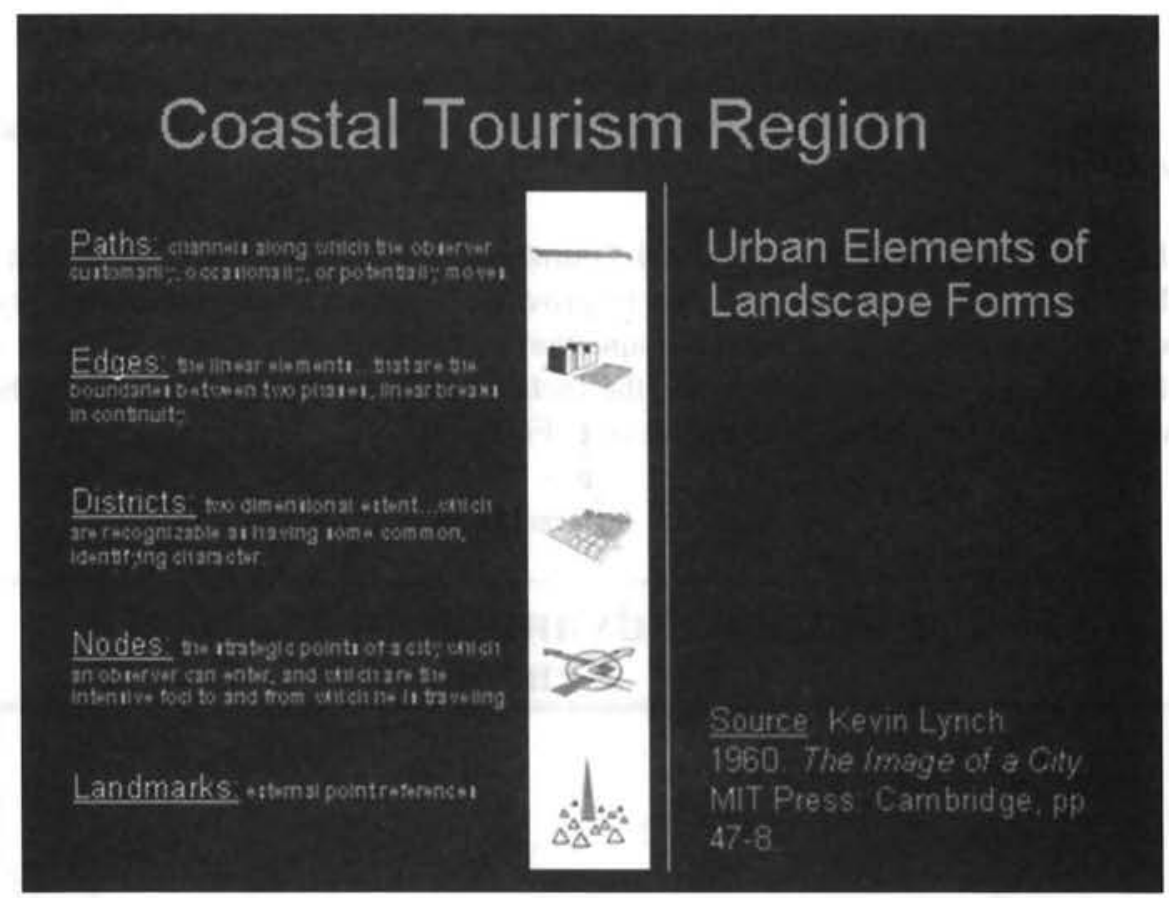

\section{INCHEON LEISURE PORT APPLICATION}

\section{Incheon Leisure Port Elements}

Some of the tourism planning distinctions introduced above are here applied in a very preliminary way to the Incheon Leisure Port project. In the Incheon context, principal participants and stakeholders in Broker-Local-Tourist System include: ${ }^{10}$

\section{Public Sector Brokers}

- Ministry of Maritime Affairs and Fisheries (MOMAF)

- Incheon Metropolitan City

- Inha University ${ }^{11}$

\section{Private Sector Brokers}

- Domestic and International Tourism Industry entities (e.g. hotel, resort, and transportation companies and conglomerates; tourism service providers)

Locals

- Residents living in the Greater Incheon Region

\footnotetext{
${ }^{10}$ For an introduction to the national context of Incheon coastal tourism, see Kim and Kim (1996).

" Alternatively, universities may be considered as "academic sector brokers."
} 


\section{Tourists}

- Domestic Tourists from parts of Korea outside the Greater Incheon Region

- International Tourists (e.g., American, Chinese, Russian, Canadian, Australian tourists)

In the Incheon context, the Coastal Tourism Region is broadly equated with the Yellow Sea contours of Gyeonggi-do (a province that surrounds the capital city of Seoul). The amenities of Incheon Leisure Port are located in a geographic area that Kichan Park has shown to encompass the Incheon Seaport, Incheon Airport, Incheon Business Port, and Incheon Technoport (see, Figure 8).

Figure 8. Incheon Pentaport

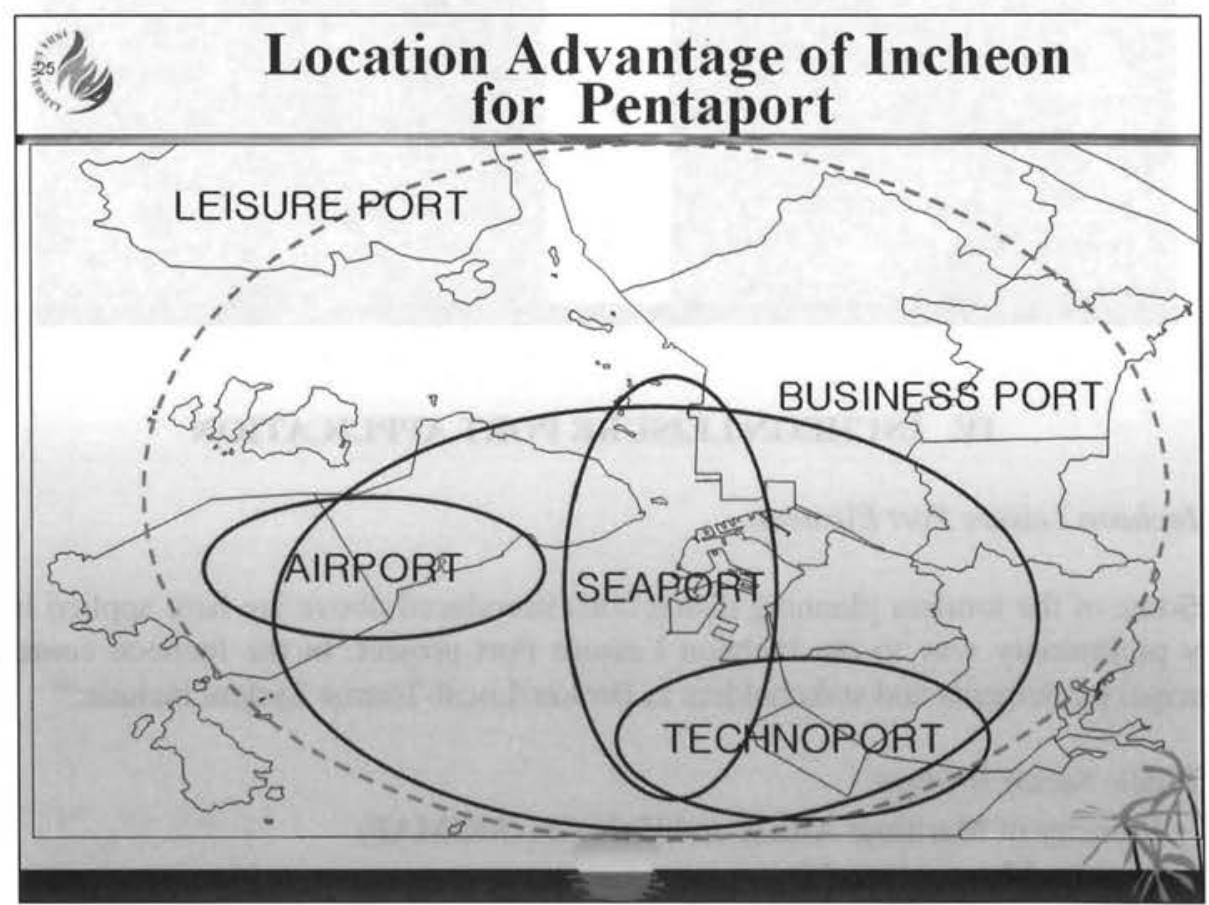

Source : Adapted from Prof. Kichan Park, "Networking Strategy of Pentaport Project." Pentaport Seminar to Develop Incheon as Logistics Hub in NEA, 27-28 October, 2003, Inha University, Incheon.

\section{Incheon Tourism Zone}

- Broadly speaking, the Incheon tourism zone denotes those areas within the full jurisdiction of Incheon Municipal City in which touristic (and recreational) activities are conducted and planned. Thus, the tourism zone encompasses leisure destinations, services, and routes.

\section{Incheon Tourism Core}

- Historically, the tourism and commercial core of Incheon has been on the 
mainland in Jung-gu (district). With the Incheon Pentaport development agenda this will change so that the tourism core will be defined by the tourism and leisure facilities found on lands and islands surrounding Incheon International Airport. For convenience this is labeled the leisure component of the Yongudo-Incheon International Airport-Yeongjongdo (YIIAY) complex.

Figure 9. Incheon Tourism Itinerary Types

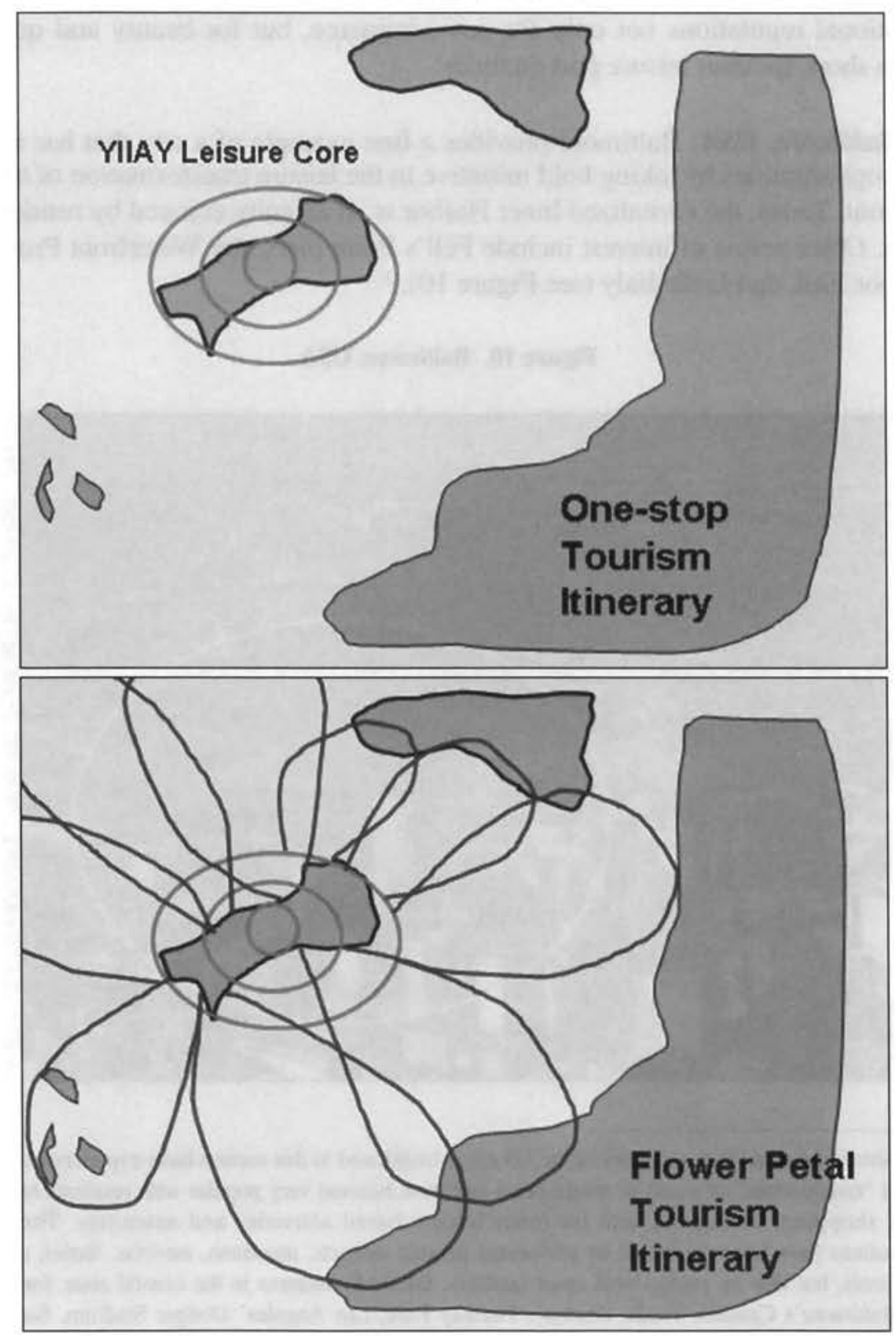




\section{International Benchmarks}

For the Incheon Leisure Port that emerges to be of the very highest quality, government decision-makers and industry leaders in Korea are wise to consider other highly regarded cosmopolitan ports, which have in one way or another become multifunctional. In the North America and elsewhere, a number of ports are especially relevant to the Pentaport Project for how their configurations meet practical and aesthetic standards of excellence. Importantly, the ports identified below have international reputations not only for sea commerce, but for beauty and quality of life-in short, for their leisure port qualities.

- Baltimore, USA : Baltimore provides a fine example of a city that has adjusted to new opportunities by taking bold initiative in the leisure transformation of an urban waterfront. Today, the revitalized Inner Harbor is an amenity enjoyed by residents and tourists. Other points of interest include Fell's Point piers, the Waterfront Promenade in Harbor East, and Little Italy (see Figure 10). ${ }^{12}$

Figure 10. Baltimore, USA

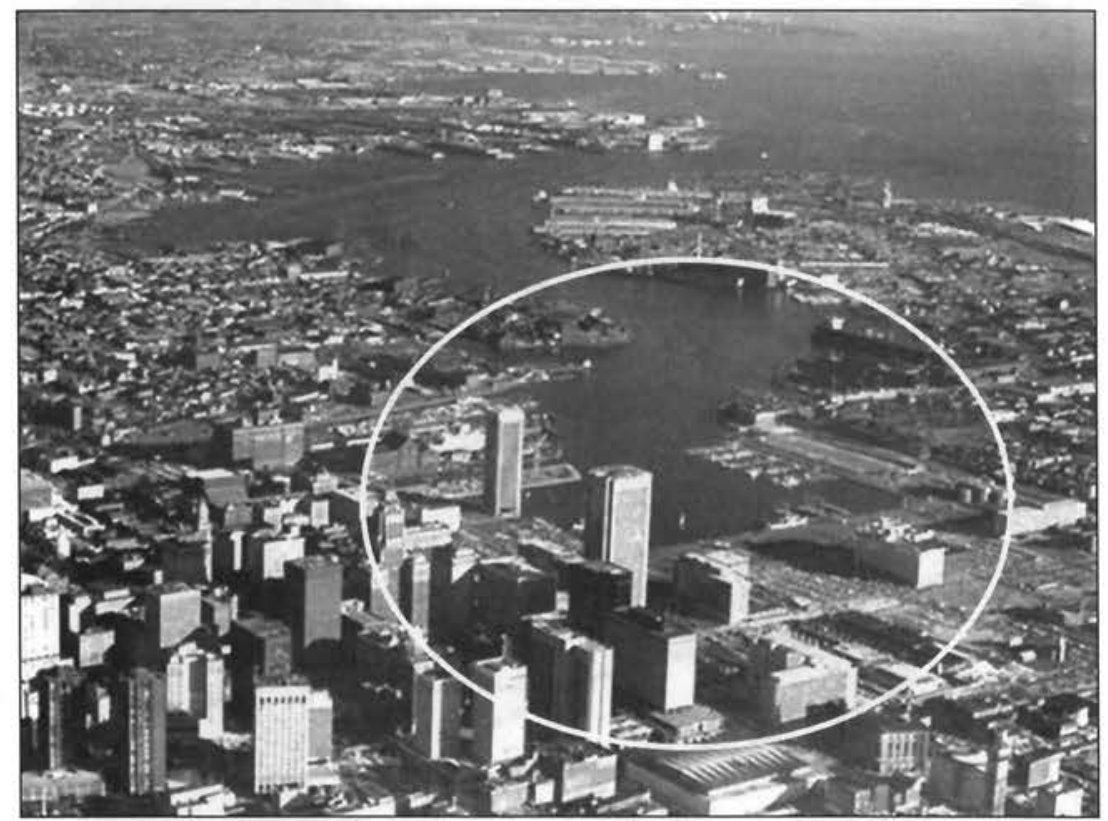

${ }_{12}$ It should be noted that a number of the US cities mentioned in this section have experienced economic and social "renaissances" of a sort in recent years and have become very popular with residents and visitors alike for shopping, dining out, and for other leisure-based activities and amenities. These urban transformations have been facilitated by revitalized historic districts, museums, marinas, ferries, and cruise ship terminals, but also by professional sport facilities. Baseball stadiums in the coastal zone, for example, include Baltimore's Camden Yards, Boston's Fenway Park, Los Angeles' Dodger Stadium, San Diego's PETCO Park, Seattle's Safeco Field, and San Francisco's SBC Park. 


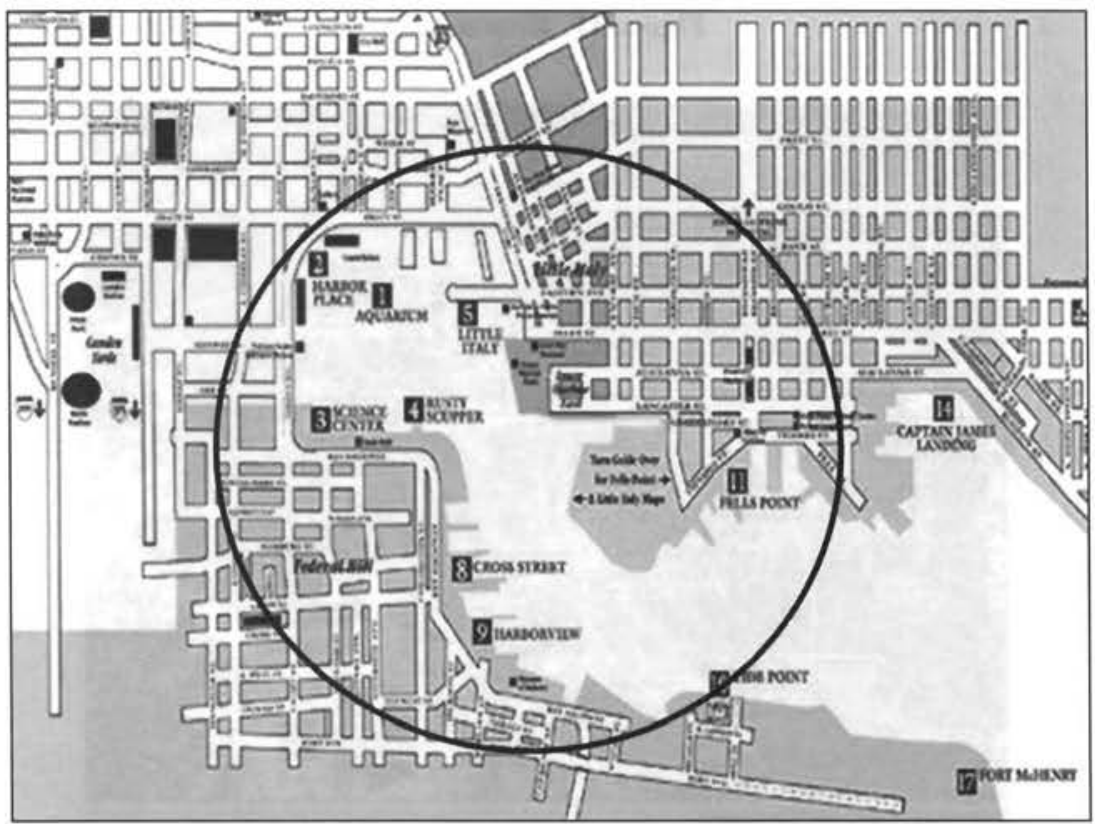

http://www.mdarchives.state.md.us/msa/speccol/photos/eye/html/z083.html http://www.golombard.com/about directions map.html

- Boston, USA: Boston has a long history as a seaport and cultural center. Over the last years, the city has made major revisions in controlling highway traffic through the city and in facilitating access to the airport. Points of interest include Faneuil Hall (a meeting place and marketplace since 1742), the USS Constitution ("Old Ironsides"), wharfs in the North End and in the Seaport District, Boston Commons, and the Charles River Esplanade (see Figure 11). 
Figure 11. Boston, USA
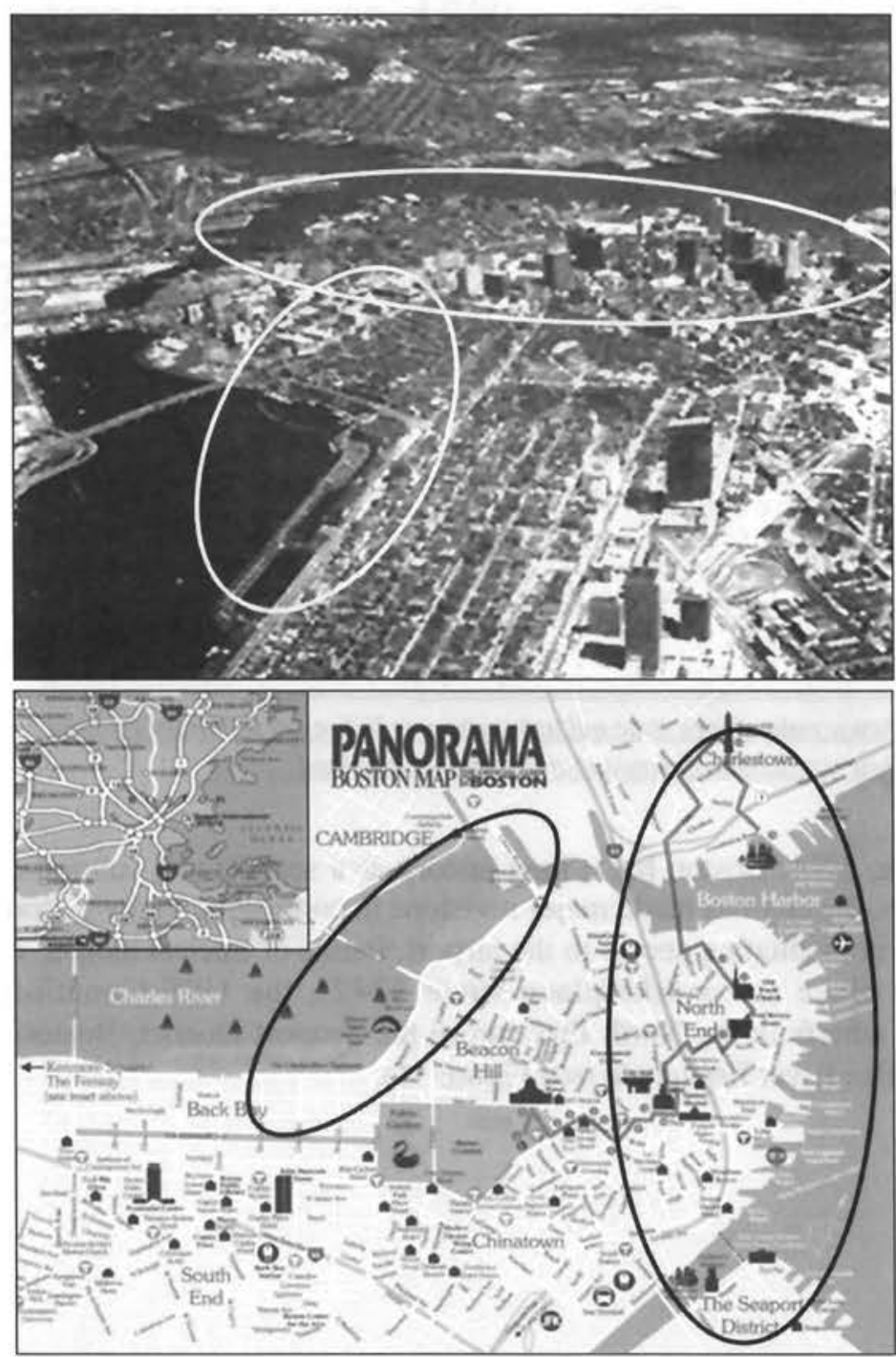

http://www.rst.gsfc.nasa.gov/Sect6/Boston.JPG

http://www.panoramamagazine.com/panoramamagazine/images/boston map.gif

- Honolulu, USA: Military and industrial uses of Honolulu are centered in Pearl Harbor. The Honolulu Leisure Ports encompasses Waikiki and stretches from Diamond Head to the Downtown District. Aloha Tower-a marketplace situated on a pier-has been a Honolulu landmark since 1926. Recently revitalized to increase the number of restaurants and retail stores, Aloha Tower has been very successful in successful in attracting not only tourists, but residents to the waterfront (see Figure 12). 
Figure 12. Honolulu, USA
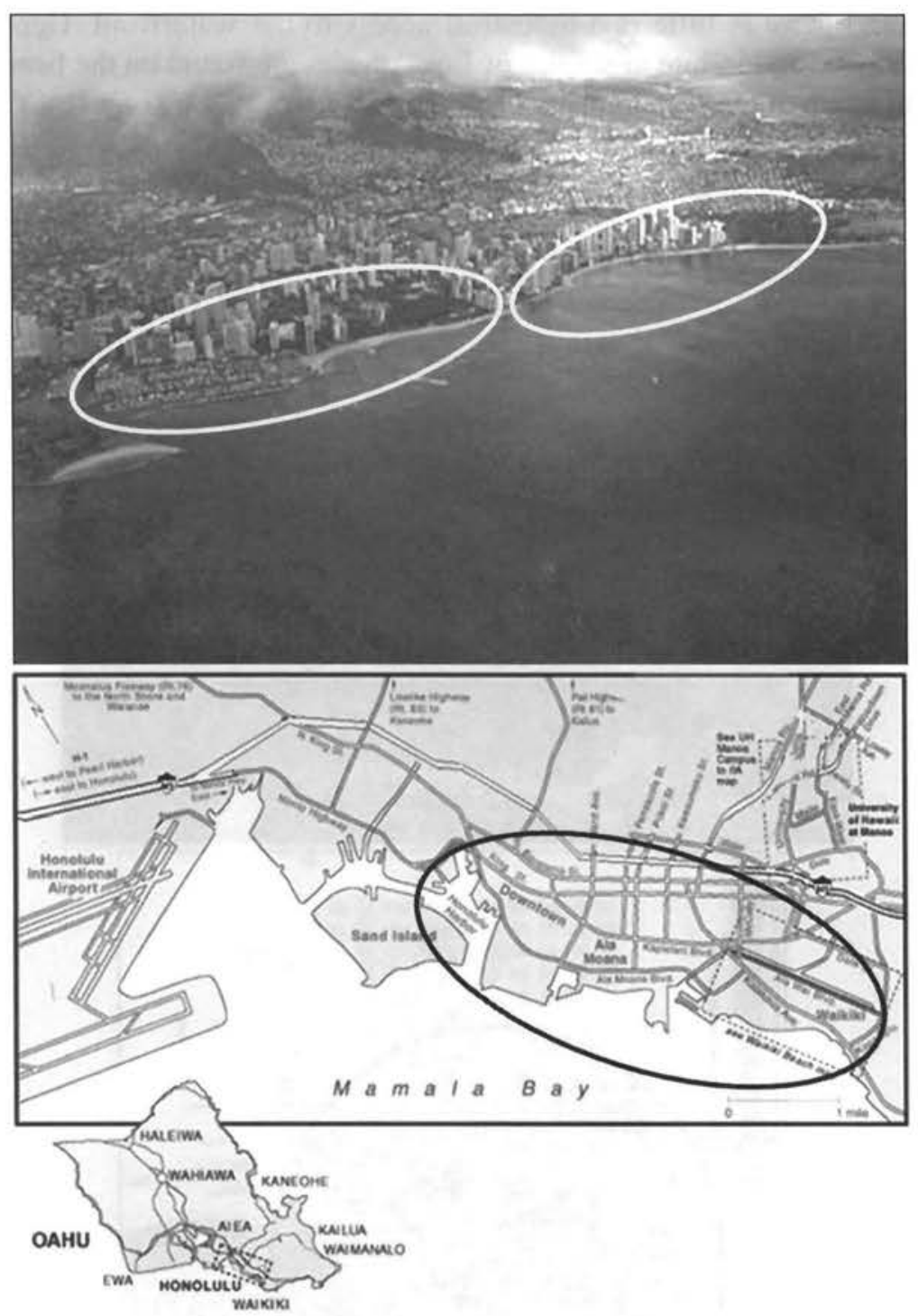

Adapted from:

http://www.peterlanger.com/Countries/Southpacific/Hawaii/pages/HIHON002.htm Adapted from:

http://www.ifa.hawaii.edu/ifa/maps/map honoluluc800-3bit.gif 
- Los Angeles, USA: The Port of Los Angeles (and the adjacent Port of Long Beach) is rather cut-off functionally and divorced sociologically from the city of Los Angeles and there is little non-industrial access to the waterfront. Generally, the coastal touristic and leisure amenities of Los Angeles are found on the beaches to the North and South of the seaport district (see Figure 13).

Figure 13. Los Angeles, [and Long Beach] USA

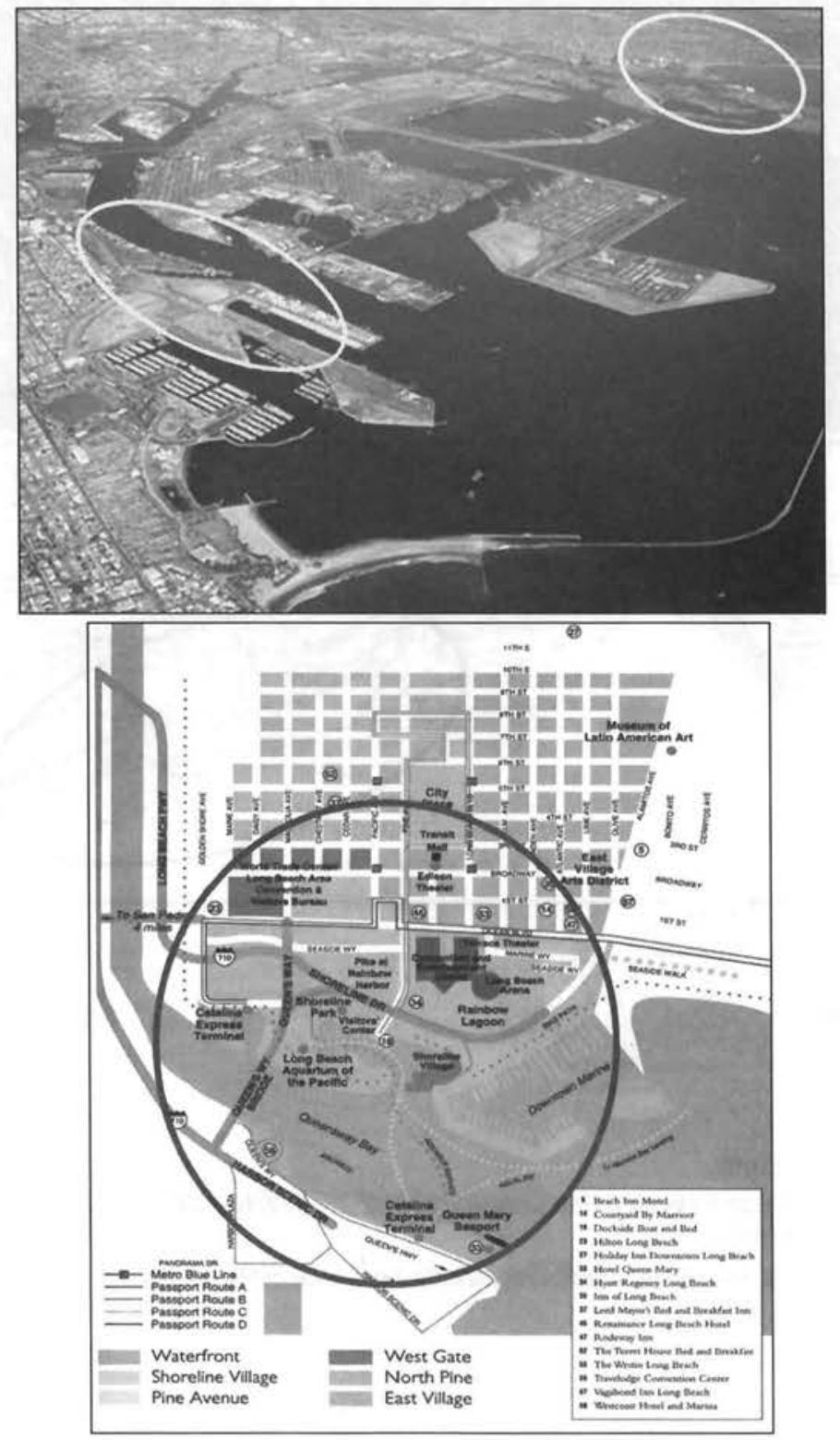

http://www.portoflosangeles.org/aerial.htm http://www.longbeachshow.com/images/lbmap.gif 
- San Diego, USA: San Diego provides a good example of a city that sustains its shipping and naval industries while at the same time encouraging recreation and tourism in the waterfront areas. Popular leisure amenities include Balboa Park, Old Town, Shelter Island, Seaport Village, the Embarcadero, the Maritime Museum, Mission Bay Aquatic Park, and the Hotel Coronado (see Figure 14).

Figure 14. San Diego, USA
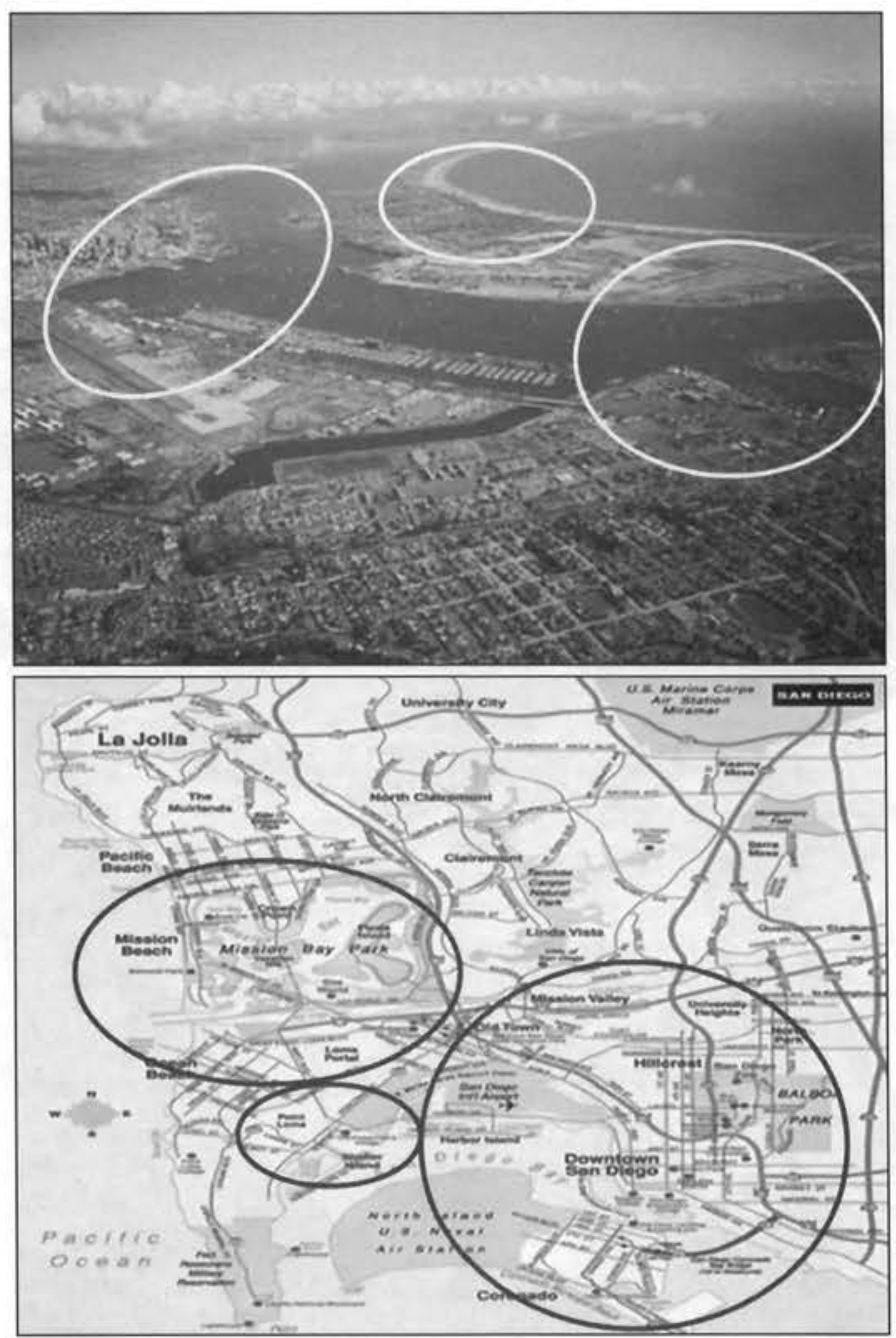

http://map.sdsu.edu/group2003/group6/photo.htm

http://www.wherela.com/images maps/SD map 2b.jpg 
- San Francisco, USA: San Francisco resembles Boston in that it has a long history of seaborne trade and cultural achievement. Its Leisure Port elements include the Marina District (and Sausalito) near Golden Gate Bridge, Golden Gate Park, and Fisherman's Wharf (see Figure 15).

Figure 15. San Francisco, USA
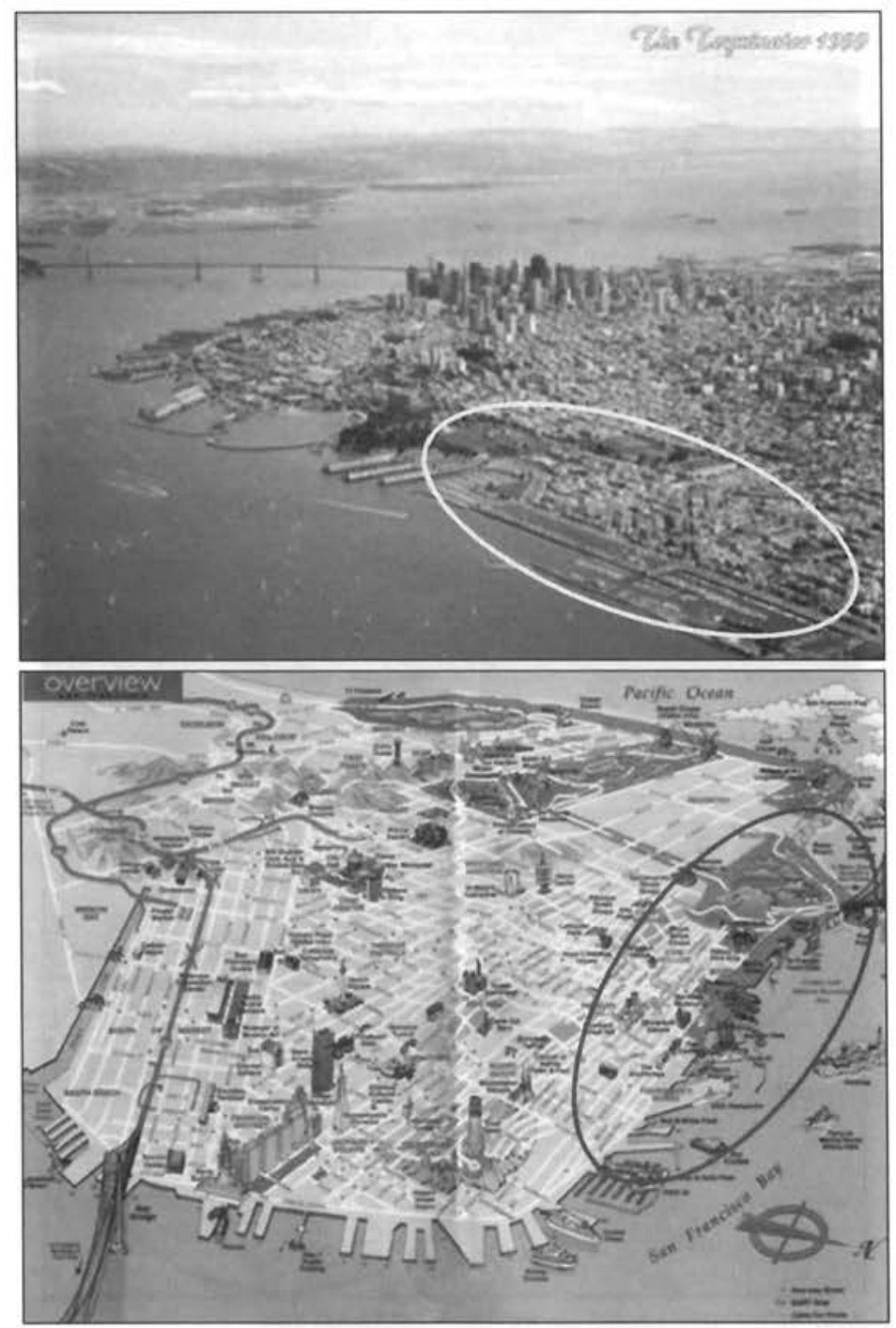

http://pages.prodigy.net/toyminator/cisco.html http://www.myroadtrips.com/sfloverview.jpg 
- Seattle, USA: Although Seattle has a distinguished maritime history, recent advances in container and port technologies and a competitive market have caused some shipping lines to move their business to the nearby Tacoma (see, Hershman and Chamberlin, 2003). In response, Seattle has focused new attention on developing it Central Waterfront. This effort has involved a major cruise terminal, and a marina. In addition, the city considers increasing the access to the waterfront by removing the overhead Alaskan Way Viaduct. Other important touristic destinations include Pioneer Square, Pike's Place Market, Odyssey Maritime Discovery Center, and the Seattle Aquarium (see Figure 16).

Figure 16. Seattle, USA
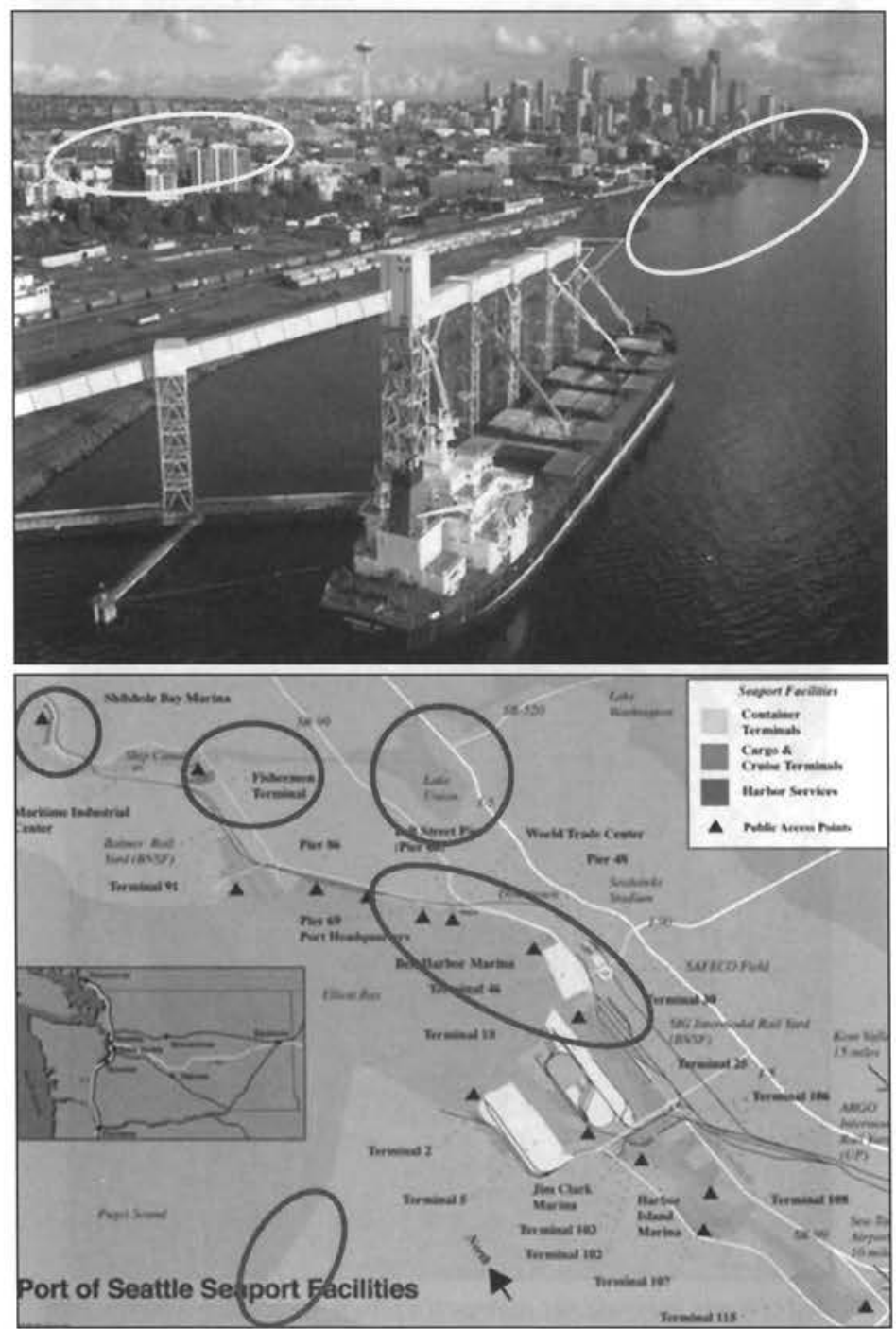

http://www.avsim.com/pages/1099/fu3/fs-064.jpg

Courtesy of Port of Seattle 
- Sydney, Australia: Sydney in many respects resembles Vancouver, British Columbia. Both cities are located at the mouths of rivers and have neighborhoods linked by major bridges. Sydney's Leisure Port amenities are found within the harbor, especially in areas close to the architecturally distinctive Opera House, and also on beaches facing the ocean (see Figure 17).

Figure 17. Sydney, Australia
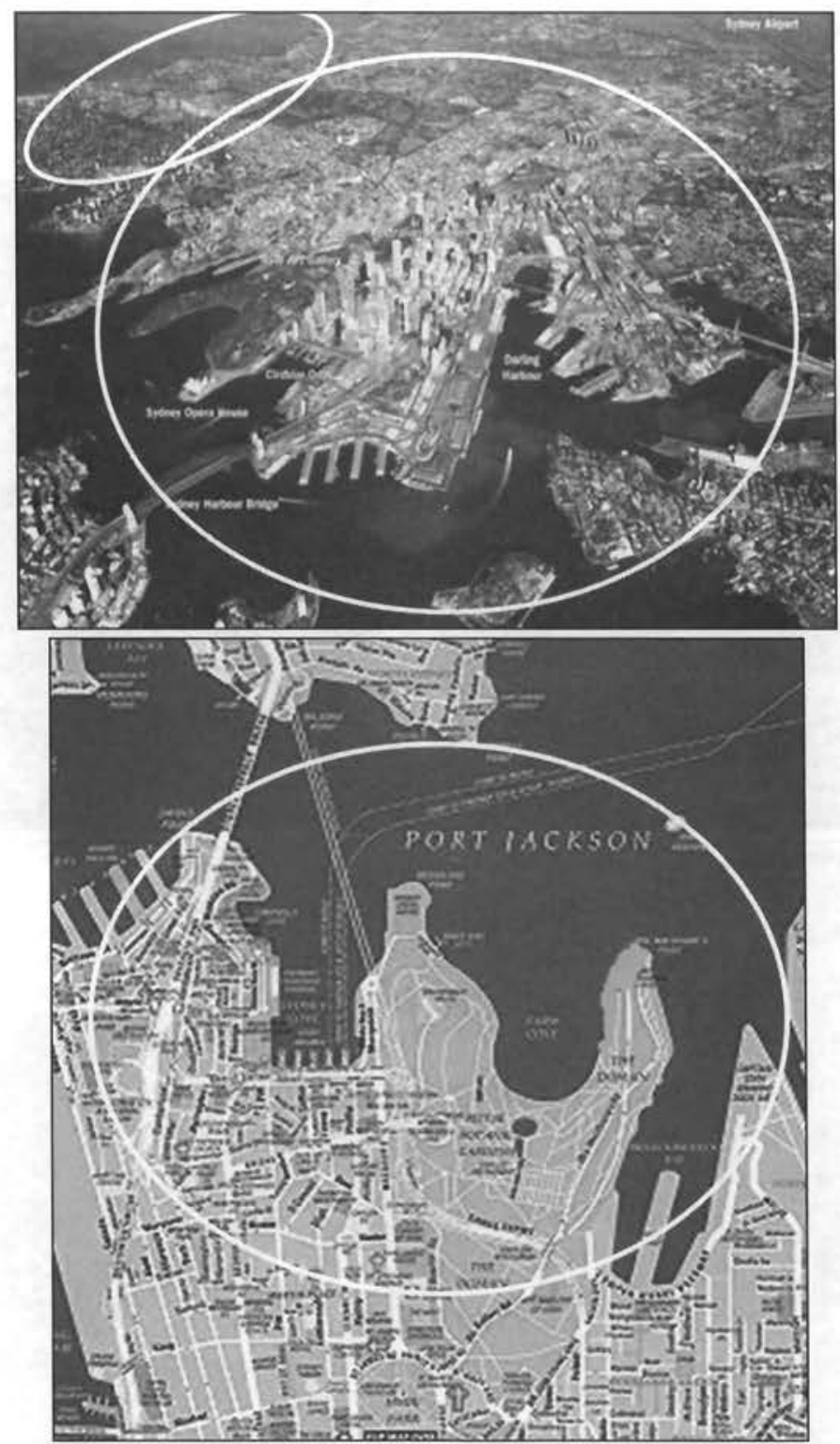

http://users.bigpond.net.au/markbell/new-web/main-window.htm Adapted from http://www.3dphoto.net/stereo/world/australia pacific/nsw/sydney/map-sydney-close up.jpg 
- Tokyo, Japan: Tokyo has invested heavily in developing leisure port amenities. Popular downtown areas include Shiodome, Ginza, and Marunouchi. The Rainbow Bridge (designed with a loop so riders see more of the city and waterfront) provides quick access from these districts to Odaiba-a large-scale amusement zone offering shopping, entertainment, food, and as well as access to the beach. The Tokyo Disneyland-Tokyo Disney Resort-Tokyo Disney Sea complex attracts many international and domestic visitors (see Figure 18).

Figure 18. Tokyo, Japan
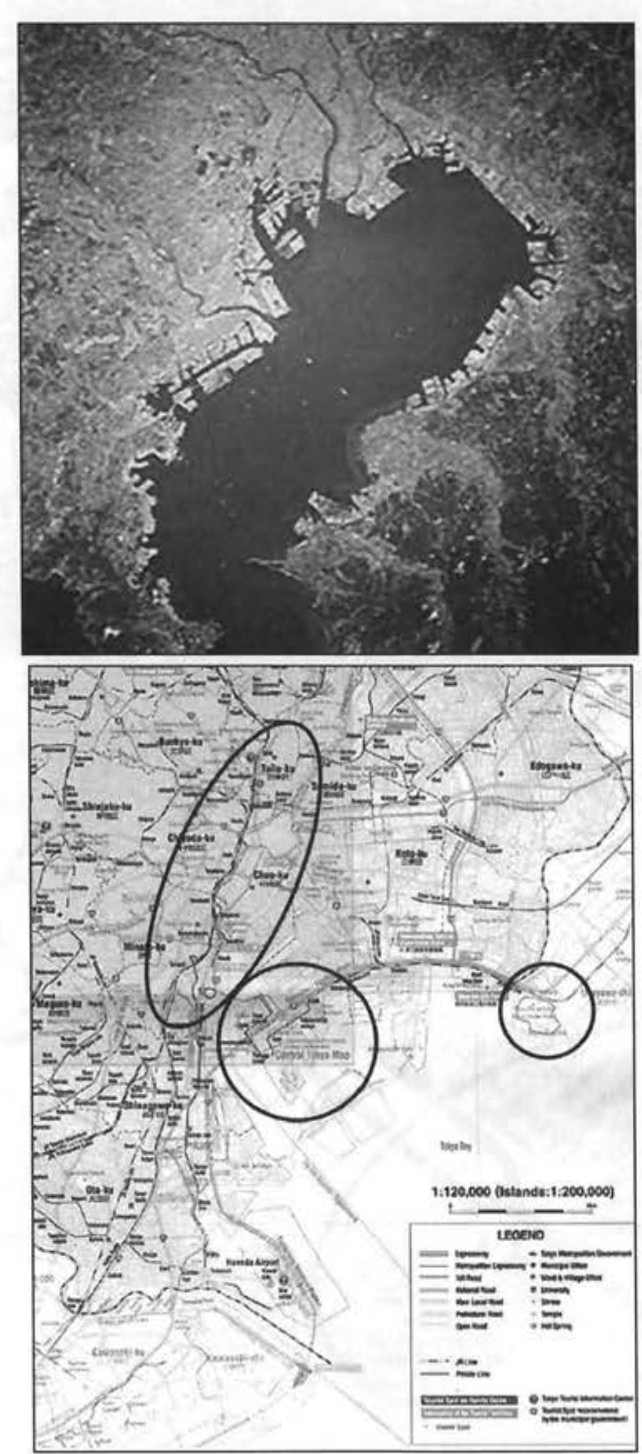

http://rst.gsfc.nasa.gov/Sect12/originals/Fig12 32.jpg http://www. tourism.metro.tokyo.jp(Tourism Division) 
- Vancouver, British Columbia: Vancouver is known internationally for its natural beauty and also its cultural sophistication. The Downtown District boasts a fine cruise ship terminal. Also in close proximity are the leisure amenities of Darling Harbor, Stanley Park, and Granville Island (see Figure 19).

Figure 19. Vancouver, Canada
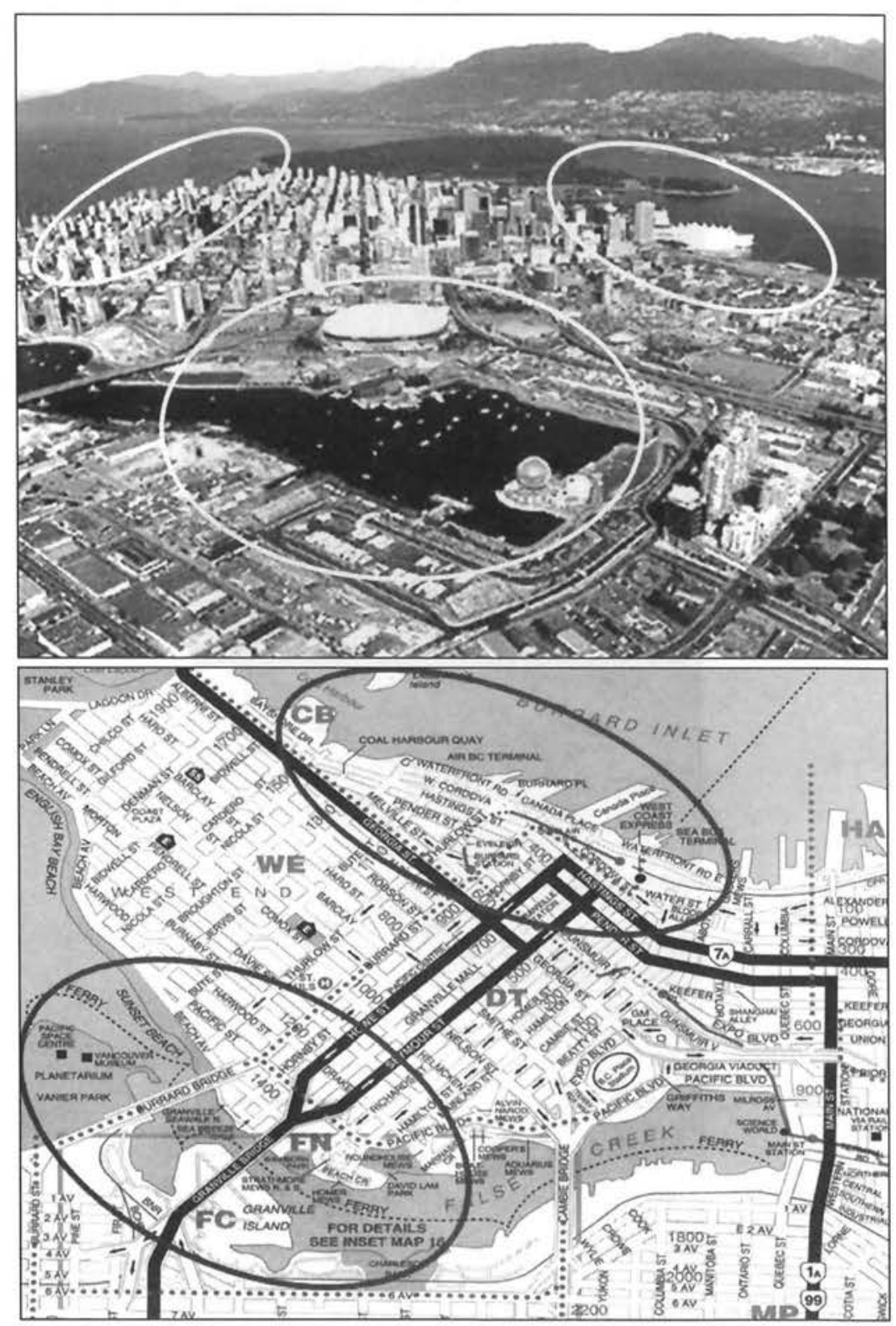

http://members.shaw.ca/robkwong/aerial photo of vancouver bc.htm http://www.vancouverbcrealty.com/maps/coalharbour/downtown.html 


\section{Incheon Leisure Port Planning}

The Pentaport transformation under discussion is of enormous proportions. Looking to the leisure port element, one is again reminded how it is that coastal zone issues are inherently controversial. Because the landscape features and resources of the coastal zone are so varied and prized, the human constituencies that seek to visit, reside, and work in the zone quickly find themselves in competition. Thus, the attraction of diverse coastal amenities leads to congestion and to multiple-use and multiple-value conflicts.

Without question, the development of the Incheon leisure port and the Pentaport Project in which it is major component jointly represent the fruits of visionary planning and design efforts. For Incheon to evolve in a truly sustainable way according to the Pentaport agenda, however, a variety of technological, logistic, and human relations issues must be addressed and resolved.

The development of a sustainable Incheon Leisure Port will depend, in part, on changes in some of the operations and goals of its Seaport. The fundamental business of shipping ports has always been to move and handle cargo in efficient ways. Now, port authorities around the world are adjusting to both support leisure port initiatives in their area and-in some cases - to diversify internally in order to take advantage of leisure-based opportunities and responsibilities.

The Incheon Seaport and the Incheon Leisure Port can thrive together. As portions of Incheon are reconfigured in the development of marinas, seaside parks, promenades, seafood restaurants, and related touristic businesses, a large number of domestic and international visitors will be drawn to the waterfront. This change will create new consumer demands for leisure products and services, but success is conditional on quality of life perceptions. Certainly, a clean Incheon Seaport is a prerequisite for a viable Leisure Port.

\section{Demand Estimation}

\section{Coastal Passengers}

There are 154 islands in the waters around Incheon which account for $5 \%$ of the total number in Korea. The islands are linked by passenger boats based in the Incheon coastal ferry terminal. Forty-two of the islands are inhabited and most show a major potential for marine tourism development. Nonetheless, only a few have developed until now because of the difficulty of marine transportation and shortage of water and electricity on the islands.

In1998, the International Passenger Quay Extension was completed in Incheon Port to supplement the existing facilities in the Inner Harbor and to accommodate the growing numbers of international passengers, especially those bound for China. In 2000 , the Passenger Terminal was opened for residents and visitors bound for islands in the Incheon vicinity. Today, all of these terminals are being highly utilized for marine activities including tourism. 
Table 1 below provides figures for coastal passengers traveling to and from islands in the Incheon region, and also the proportion of the national total these represent.

Table 1. Incheon Passenger Boat Traffic

Incheon Passenger Boat Traffic

\begin{tabular}{r|r|r|r}
\hline Year & $\begin{array}{l}\text { Total No. of } \\
\text { Passengers(thousand) }\end{array}$ & $\begin{array}{l}\text { No. of Incheon } \\
\text { Passengers(thousand) }\end{array}$ & $\begin{array}{l}\text { Proportion of Incheon } \\
(\%)\end{array}$ \\
\hline \hline $\mathbf{1 9 7 0}$ & 5,869 & & \\
\hline $\mathbf{1 9 7 5}$ & 5,908 & & \\
\hline $\mathbf{1 9 8 0}$ & 8,580 & & \\
\hline $\mathbf{1 9 8 5}$ & 8,534 & 975 & 11.8 \\
\hline $\mathbf{1 9 9 0}$ & 8,260 & 974 & 11.2 \\
\hline $\mathbf{1 9 9 5}$ & 8,702 & 1,260 & 11.7 \\
\hline $\mathbf{1 9 9 7}$ & 9,899 & 1,129 & 13.6 \\
\hline $\mathbf{1 9 9 8}$ & 8,277 & 1,098 & 11.8 \\
\hline $\mathbf{2 0 0 1}$ & 9,339 & 887 & 9.4 \\
\hline $\mathbf{2 0 0 2}$ & 9,459 & &
\end{tabular}

- Annual Increasing Rate (1970-2002) : $1.5 \%$

Table 1 shows that in the case of Incheon, the number of passengers that have been routed through Incheon has varied around a million people per year since reaching a total of $1,260,000$ people in 1997. 
Table 2 below shows figures regarding the purposes of coastal ferry traffic.

Table 2. Incheon and Korean Passenger Boat Traffic

\section{Incheon and Korean Passenger Boat Traffic}

\begin{tabular}{|c|c|c|c|c|c|c|c|c|}
\hline \multicolumn{2}{|l|}{ Items } & \multicolumn{6}{|c|}{ Travel Purposes } & \multirow[t]{2}{*}{ Total } \\
\hline & & Journey & Business & $\begin{array}{l}\text { Visit to } \\
\text { Family }\end{array}$ & $\begin{array}{l}\text { Attend } \\
\text { School }\end{array}$ & Commuting & Others & \\
\hline \multirow[t]{2}{*}{ Incheon } & Cases & 6,101 & 433 & 237 & 18 & 75 & 406 & 7,270 \\
\hline & $\begin{array}{l}\text { Proportion } \\
(\%)\end{array}$ & 83.9 & 6.0 & 3.3 & 0.2 & 1.0 & 5.6 & 100.0 \\
\hline \multirow[t]{2}{*}{ Nationwide } & Cases & 27,055 & 2,827 & 4,424 & 86 & 5,677 & 2,046 & 42,115 \\
\hline & $\begin{array}{l}\text { Proportion } \\
(\%)\end{array}$ & 64.2 & 6.7 & 10.5 & 0.2 & 13.5 & 4.9 & 100.0 \\
\hline
\end{tabular}

- Data : Korea Maritime Institute, 2002 National Transportation Data Base Project, 2002

Based on this data and using a 5.5 percent growth rate, we used a Holt exponential smoothing model and simple regression to estimate the total number of national passengers for the target year of 2012. Among the models, the simple regression model is appraised to be a most realistic forecast, and so we adopted this forecasted estimate. After estimating national total of passengers, we obtained the Incheon portion using the last three year average portion of Incheon, 11.6\%. Among the Incheon portion, $84 \%$ are estimated to be the travelers. 
Table 3 below shows a forecast for costal passengers in Korea and in the Incheon area.

Table 3. Forecast of Coastal Passengers

Forecast of Coastal Passengers (unit:Thousand Persons)

\begin{tabular}{l|r|r|r}
\hline Items & National Total & \multicolumn{1}{|c|}{ Incheon } & \multicolumn{2}{|c}{$\begin{array}{c}\text { Travelers in } \\
\text { Incheon }\end{array}$} \\
\hline \hline $\mathbf{2 0 0 4}$ & 9,882 & 1,146 & 963 \\
\hline $\mathbf{2 0 0 6}$ & 10,387 & 1,205 & 1,012 \\
\hline $\mathbf{2 0 0 8}$ & 11,027 & 1,279 & 1,074 \\
\hline $\mathbf{2 0 1 0}$ & 11,820 & 1,371 & 1,151 \\
\hline $\mathbf{2 0 1 2}$ & 12,782 & 1,482 & 1,245 \\
\hline
\end{tabular}

In the year $2000,1,330,000$ passengers used the Incheon ferry terminal. Our forecast shows that number of passengers in Incheon will amount to $1,482,000$ people by the year 2012, representing an estimated $11.5 \%$ of increase. Given this result, It is not expected that the ferry terminal will need further expansion and it is appraised that current coastal ferry terminal should be used until 2012 as it is.

\section{Beach Use}

Table 4 below shows forecast figures for beach use by coastal passengers in the Incheon area. 
Table 4. Forecast of Coastal Passengers

\begin{tabular}{|l|r|r}
\hline \multicolumn{3}{|c|}{ Forecast of Coastal Passengers (unit:Thousand Persons) } \\
\hline Items & $\begin{array}{c}\text { Current Growth Rate } \\
(\mathbf{1 3} \%)\end{array}$ & 7\% Growth Rate \\
\hline \hline $\mathbf{2 0 0 1}$ & 3,138 & 3,138 \\
\hline $\mathbf{2 0 0 4}$ & 4,637 & 3,844 \\
\hline $\mathbf{2 0 0 6}$ & 6,016 & 4,401 \\
\hline $\mathbf{2 0 0 8}$ & 7,804 & 5,039 \\
\hline $\mathbf{2 0 1 0}$ & 10,125 & 5,769 \\
\hline $\mathbf{2 0 1 2}$ & 13,135 & 6,605 \\
\hline
\end{tabular}

There are 34 beaches in the Incheon area, which represents nearly $10 \%$ of the total 350 beaches in Korea. In 2001, The 3,138 thousand persons (5\% of the total beach goers) visited Incheon beaches.

One reason for the low beach use is that beaches in Incheon are difficult to reach because they are located far from the mainland. The beach use growth rate for the 1999-2001 period is estimated to be $13 \%$ nationwide, and almost the same rate describes beach use in Incheon.

To forecast the number of future beach goers, it is estimated that the growth rate will drop from $13 \%$ to $7 \%$, because as personal income increases, the number of beach-goers declines rapidly. The elasticity of beach going to income is expected to be less than 1.0 in the future because of people's diversification in leisure and sports activities as income increases. In this case, the number of beach-goers in 2012 is estimated to be $6,600,000$ persons in Incheon, almost twice that of 2001 . If the current growth rate is employed in the estimation calculation, the number of projected beachgoes would quadruple. Given these estimates, it is clear that the existing leisure facilities in beaches in Incheon should become expanded at least a factor of two in order to meet the future demand.

\section{Marine Leisure Equipment}

Table 5 shows figures regarding marine leisure equipment that will be used in Korea and Incheon in the future. 
Table 5. Forecast of Leisure Equipment in the Future

Forecast of Leisure Equipment in the Future

\begin{tabular}{l|r|r|r|r|r|r}
\hline \multirow{2}{*}{ Items } & \multicolumn{2}{l|}{2003} & \multicolumn{2}{l|}{2006} & \multicolumn{2}{l}{2012} \\
\cline { 2 - 7 } & Total & Incheon & Total & Incheon & Total & Incheon \\
\hline \hline Motor boats & 2,594 & 560 & 3,002 & 660 & 4,023 & 885 \\
\hline Yachts & 382 & 84 & 442 & 97 & 592 & 130 \\
\hline Water-bike & 481 & 105 & 557 & 122 & 746 & 164 \\
\hline Water-ski & 936 & 206 & 1,083 & 238 & 1,451 & 319 \\
\hline Surf-board & 1,843 & 405 & 2,34 & 469 & 8,945 & 1,968 \\
\hline Others & 12,002 & 2,629 & 13,893 & 3,055 & 15,757 & 3,466 \\
\hline
\end{tabular}

The number of marine leisure facilities in Incheon is estimated to be 2,629 units as of the end of 2003, which is $22 \%$ of the national total units. This number-which includes motor boats, yachts, water-bikes, water-ski, and other equipment-also includes units held by water leisure companies and those owned by private citizens. The growth rate of marine leisure facilities is assumed to be $5 \%$, if the trends of foreign cases such as Japan and European countries are any indication. Table 5 also shows that it is estimated the total number of marine leisure facilities in Incheon will increase by 837 units during the $2003-2012$ period.

\section{Zoning Plan for Incheon Leisure Amenity Destinations}

It is recommended that comprehensive land and water use planning in Incheon Leisure Port is undertaken with an explicit appreciation of the unique historical, ecological, and other characteristics of sub-areas. With this in mind, what follows is suggested template for the zoning and development of 10 general areas-termed Incheon Leisure Amenity Destinations - in accordance with appropriate development themes (see, Map 1). ${ }^{13}$

\footnotetext{
${ }^{13}$ Most of the destinations listed fall within the jurisdiction of Jung-gu [a district of Incheon]. Notable among Yellow Sea islands not discussed here include Jawoldo and Saseungbongdo to the southwest of Incheon and Socheongdo, Soyeonpyeongdo, and Daeyeonpyeongdo and Daecheongdo to the northwest. Nor are numerous fishing villages to the south of Incheon with ecotourism and ethnic tourism appeal treated here.
} 


\section{Downtown Metropolitan and Port Area}

Notable leisure amenities are presently found in the mainland portions of Jungugu and in Yonsu-gu [districts of Incheon]. Notable attractions are found in the areas of Wolmido, Eulwangi Beach, Yeon-an Pier, and the Songdo Resort. A diverse set of industrial plants, ferry terminals, fishery ports, touristic facilities, and other waterdependent facilities are found along the area's waterfront. In some places, military fences (built to defend Incheon from the infiltration by Democratic Peoples Republic of Korea agents) block public access to waterfront. A modest example of waterfront development has taken place around the small island of A-am-do near Songdo.

The Incheon Leisure Port development theme for this area is identified as waterfront development for citizens and visitors. Planning recommendations regarding the downtown are as follows:

- The military fences should be eliminated or, if possible, to be substantially redesigned and made more aesthetically pleasing .

- Large stretches of the waterfront and the Incheon Inner Harbor should be opened to the public with the development of promenades, seaside parks, fishing piers, restaurants, and so forth. In this regard, the city government has already revealed their plans to develop several areas as a waterfront park within 3 years.

- Sorae fishery port - a popular destination in the south of Incheon-should be linked to a neighboring Sorae salt pond eco-park. This would thereby establish an eco-corridor in southern Incheon.

\section{Songdo New Town Area}

Songdo-a man-made island and a main component of the Free Economic Zone-is envisioned to include a large residential area, a hi-Tec park, a seaside park, a commercial park, and a 200-boat marina, among other leisure amenities and attractions. This would be the focal point for the marine and seaside activities in the future if they are developed systematically.

The Incheon Leisure Port development theme for this area is identified as residential and business-related development.

\section{Yongudo-Incheon International Airport-Yeongjongdo (YIIAY) Area}

In this Free Economic Zone, the YIIAY complex has steadily expanded the number of leisure, tourism, entertainment, shopping, and hotel facilities. There are famous beaches on neighboring Muui Island, and movie set facilities on Silmi Island. Tidal flats in the area used by ecotourists.

The Incheon Leisure Port development theme for this area is identified as islandbased resort development for foreigners and domestic tourists. Future plans call for a 200-boat marina, a sea-world style of theme park, additional hotels, and amusement facilities.

The YIIAY complex (with its airport as the pivotal facility) will become the 
primary international tourism attractor as it grows in importance as the Incheon tourism core. Thus, it is anticipated that Incheon Pentaport tourism will radiate outward in concentric circles from the "air/leisure port" complex.

\section{Cheongra Area}

The Cheongra area of reclaimed land has multiple potentials to be an international business center, and also a residential complex with "leisure and sports facilities such as theme parks and golf courses" (Jun, 2003:92).

The Incheon Leisure Port development theme for this area concerns mixed-use leisure development. Discussion is underway regarding tourism and recreation amenities that would include a sea-world complex of aquaria, educational and ecotourism facilities in combination with hotel accommodations and services.

\section{Ganghwa Area}

Ganghwa-gun (county) tourism destinations include forts, temples, and tidal flats. ${ }^{14}$ Several education centers for tidal flat appreciation are located on the southern shoreline of Ganghwa and at nearby coastal locations. Presently, Ganghwa Island is linked to the mainland by two bridges. In the future, greater access to the island will be made possible by the new passenger boats and bridges. Of course, the Ganghwa area is of great significance for its proximity to the Demilitarized Zone between Korea and the Democratic Peoples Republic of Korea (DPRK) to the north.

The Incheon Leisure Port development theme for this area concerns both wetland preservation and appreciation and historical-military tourism. Planning suggestions are as follows:

- There is a high potential area as a wetland preservation area in the southern Ganghwa Island region, which is a base for the migratory birds and has important estuaries and tidal flats. ${ }^{15}$ This area is growing in popularity as an ecotourist destination.

- Past military remains that include fortresses, signal-fire stands, and dolmens are dominant attractions in the island. However, additional tourist facilities will be required in the near future.

\section{Jangbong Island Area}

Recently, Jangbong Island was designated by the government as a wetland preservation area. The island is well-known for its Ongam, Handeul, and Jicheon Beachs.

The Incheon Leisure Port development theme for this area concerns both wetland

\footnotetext{
${ }^{14}$ Ganghwado destinations fall within the jurisdiction of Jung-gu [ a district of Incheon].

${ }^{15}$ For the definitive volume on Korean tidal flats, with beautiful photographs, see Hong (1998). See, also, Cheong (2002).
} 
preservation and appreciation. The area (which includes smaller surrounding islands) has great ecotourism potential. Planning recommendations are as follows:

- It is necessary to create suitable tourist facilities. These are should include a visitor center and cruise terminals.

- Sand dunes in the area should be linked to the planned visitor center.

- Cruise ship access to the surrounding islands of Mo, Si and Sin should be developed . Local piers should be improved to allow access to pristine sand dunes and wetlands.

- The small islet of Ayeom is very promising for ecotourism and tidal flat tourism. Amenities there include scenic view points, restored fishermen's houses, rest houses, and a swimming pool. It will be necessary to reconstruct a local fresh-water well and to enhance other tourist facilities.

\section{Dea-i-jak Island Area}

Beaches and beautiful islands are scattered around Dea-i-jak Island. The area has long been popular as a summer resort. The area was designated by the government as a marine sanctuary in 2003 . The area is known for its beaches and sand dunes.

The Incheon Leisure Port theme for this area concerns both beach resort and ecotourism development. Planning recommendations are as follows:

- Cruise ship facilities and local piers need to be improved to allow access to sand dunes and wetlands. A visitor center is needed as well.

- Facilities on the small Saeungbong Island should be developed to encourage eco-tourism and fishing village tourism.

\section{Yeongheung Island Area}

Yeongheung Island attracts many domestic tourists to Sipripo, Changkyongri and Janggyeongri Beaches. Nearby islands include Seonjaedo and Cheukdo. Since the completion of a bridge linking Yeongheungdo to the mainland, there has been a great increase in weekend visitors.

The Incheon Leisure Port theme for this area concerns both beach resort and ecotourism development. Planning recommendations are as follows:

- A seaside resort and a 200-boat marina serving the Incheon metropolitan area needs to be developed.

- A visitor center and other facilities (e.g., lodging, pensions, parking lots, seaside roads) are needed to accommodate tourists who want a tidal flat and beach experience.

\section{Deokjeok Island Area}

Deokjeok Island and its surrounding islands (e.g., Mungapdo, Napdo, Uldo, 
Soyado, Guleopdo, Sumido, Jido, Chido, Mukdo, and Baekado) offer many opportunities for swimming, fishing, and mountain climbing. The most famous attraction on Deokjeokdo is Seopori Beach which has been popular for more than three decades.

The Incheon Leisure Port theme for this area concerns both beach resort development. Planning recommendations are as follows:

- Facilities in Seopori Beach Resort need to be expanded.

- Cruise ship facilities need to be enhanced.

\section{Baekryong Island Area}

Baekryong Island lies very close to the DPRK. Beaches and beautiful rocks and islets are scattered around the island. With changes in the touristic infrastructure, the conservation of the clean environment in the area will be a new challenging subject in the future.

The Incheon Leisure Port theme for this area concerns both beach and military tourism development. Planning recommendations are as follows:

- Bus tours and cruise tours need to be further developed in the area.

- Cruise related facilities need to be improved.

\section{Key Issues}

This section presents an assortment of preliminary observations and speculations regarding leisure realities and issues that are likely to emerge in the course of the twodecade Incheon experiment that has now begun. ${ }^{16}$

1. Incheon is in the very early stages of developing a Leisure Port to complement its Seaport and other Pentaport elements. As the urban portion of the waterfront is restructured new demands for leisure, it is essential that issues of environmental and water quality be addressed. For example, dirty import cargoes should be re-routed.

2. A great deal of the appeal of Incheon as a recreational and touristic destination is rooted in the beautiful and numerous islands in the region. For Leisure Port success, the ferry and cruise ship system in the Yellow Sea must be improved. Solution of this logistic matter will entail consideration of passenger safety, tourist motives and preferred itineraries, and industrial efficiency.

3. It must be emphasized to developers that each of the ten Incheon leisure amenity destinations has itsown unique and historically qualified character. Leisure Port planning should therefore be undertaken in a way to insure that these areas do

\footnotetext{
${ }^{16}$ Not treated here are serious social problems and vices (e.g., petty and more serious crimes against tourists, drug abuse, prostitution, corruption) often found in leisure and tourism settings.
} 
not needlessly compete where they might instead offer complementary products and services.

4. The success (or failure) of the leisure port component of the YIIAY complex will be of critical importance in the success (or failure) of the technoport and business port components of the Incheon Pentaport.

5. With the assumption that the leisure port component of the YIIAY complex is a success, visitors (both international and domestic tourists) will organize their travel in the Incheon tourism zone by two plans:

a) one-stop travel: visitors will limit their Incheon exploration to the leisure port component of the YIIAY complex (Figure 8).

b) flower petal travel: visitors will use the leisure port component of the YIIAY complex as a base and make short trips to other destinations in the Incheon tourism zone and then return to the YIIAY leisure facilities (Figure 8).

6. The success of Pentaport leisure and tourism (and also the overall quality of life found throughout Incheon) will critically depend on how people (e.g., Koreans residing in Incheon and elsewhere, diverse international visitors):

a) respond aesthetically to the juxtaposition of destinations, services, and amenities identified with Asian and Western cultural values,

[Note: This challenges tourism brokers to provide cultural contrast?but not promoting cultural conflict-in the maintenance of traditional Korean architectural and leisure values while at the same time creating modern leisure opportunities. $\left.{ }^{17}\right]$

b) and respond aesthetically to the touristic treatment of Nature. ${ }^{18}$

[Note: National parks and forms of government managed protected areas are, of course well known tools for conservation and preservation of Nature and habitat. Today, there are also now examples (e.g., along the Manzanillo coastline in Mexico) of private sector efforts (some on very large scales) to create coastal protected destinations that meet conservation objectives while at the same time encouraging visitation and enjoyment of sublime Nature.]

7. If the Incheon leisure port is successful, cross-cultural dynamics involving tourists and locals and brokers (in all combinations) will foster understanding, tolerance, and (in some instances) mimicry. If xenophilia is to be more produced

${ }^{17}$ Some scholars have remark on this tension as pitting "traditionalism" against "modernity." In the Incheon leisure and tourism context, traditionalism might be manifest in fortresses, shrines, temples, timehonored festivals, and in relatively meditative and yin appreciations of Nature. Modernism might be regarded as associated with high-tech hotel and resort enclaves, certain forms of entertainment (e.g., theme, amusement, and fantasy parks, casinos gambling), mall and luxury shopping, and relatively aggressive and yang appreciations of nature (e.g., jet skiing, parachute sailing, extreme sports). See, also, Sorensen (2003).

${ }_{18}$ Miller and Ellis (2003a and 2003b) have characterized coastal tourism development in the Incheon region as having a "culture-driven" (rather than a "nature-driven") configuration. Further, these authors have suggested private and public sector Incheon brokers have shown relatively more interest in "design questions" as compared to "impact questions." 
rather than xenophobia, then ethnocentrism will have to be understood as appropriate in some circumstances and not in others.

Two factors that deserve attention in this regard include:

a) gender differences between Asian and Western cultures, and

b) cultural homogeneity differences between Asian and Western cultures. ${ }^{19}$

8.With the tourism patterns identified above, the salient image of "Incheon" to international visitors will be that of impressive leisure and logistic infrastructure found on the YIIAY complex and associated islands (e.g., Muuido, Somuuido, Jamjindo, Silmido).

9. Leisure port development presents an extremely important challenge of destination branding. As noted above, tourism in Incheon has long been marketed (to tourists and to investors) in a manner to first highlight mainland Jung-gu. ${ }^{20}$ Now it is more strategic to tout the leisure facilities planned for the leisure component of the YIIAY complex as the Incheon tourism core.

[Note: The YIIAY complex falls within the jurisdiction of Jung-gu [district]. With this situation, one option is to continue to advance Jung-gu as the leisure core although this would require a recasting of promotional text and symbols to direct consumer and investor attention to the leisure quality of YIIAY (rather than mainland Jung-gu).

Perhaps a more exciting and profitable destination branding option is to consider an entirely new name for the YIIAY complex.] $]^{21}$

10. Just as successful leisure port development hinge on effective destination branding, so does the success of the integrated Pentaport. It cannot be underestimated how critical it is that consumers and investors "understand" what is to be discovered in Incheon that is suggested by term "Pentaport" (and constituent terms "Airport," "Seaport," "Technoport," "Business Port," and "Leisure Port").

[Note: Pentaport branding terminologies, signs, and strategies must be signal system integrity and beauty. Over the course of development, the Incheon Pentaport vocabulary can be expected to change to take advantage of new opportunities.]

${ }^{19}$ Here again, see Sorensen (2003) and also the Sorensen and Mallane paper (2003) in this volume.

${ }^{20}$ In addition to providing information about local tourism attractions on its website, the Incheon municipal government has produced an assortment of brochures and booklets for visitors complete with maps, and suggested itineraries. In these, destination categories include islands, beaches, mountains, historic sites, cultural properties (e.g., temples), parks and resorts, and tidal wetlands. Half-day, one-day, and extended tours are devoted to city tours, historic exploration, food tourism (e.g., yonghyeon-dong [monkfish]), and specialty products (e.g., Gangwhwa mugwort [wormwood] medicine, hwamuseok mats and cushions, and kkotsamap [flower-lidded baskets]).

${ }^{21}$ Las Vegas is widely known as "the entertainment capital of the world." In the event that Incheon planners decided to develop the leisure port aspects of Yongudo-Incheon International Airport-Yeongjongdo (YIIAY) complex in a way that evokes images of Las Vegas, the tourism core could be renamed something like "Entertainment Island." 


\section{DISCUSSION}

Looking ahead, and with the hope of facilitating the successful development of an Incheon Leisure Port and Pentaport, it may be useful to offer an institutional recommendation. As Miller et al. (2002) have stressed, the future of coastal tourism policies and projects depends heavily on responsible planning, regulation, monitoring and evaluation, and public education and outreach exercised by public sector, private sector and other tourism brokers.

With this in mind, it is recommended that an "Incheon Leisure Port Committee" be composed of tourism experts from government and academe to orchestrate the Incheon Pentaport transformation of the coastal leisure landscape. ${ }^{22}$ Such a group could build on the work of the several (and continuing) Inha University Pentaport seminars, and examine tourism issues and challenges discussed in the previous section. Most importantly, such a group could provide multidisciplinary research continuity to the treatment of tourism in the region and ensure broad public acceptance of the innovative Incheon Pentaport agenda.

\section{REFERENCES}

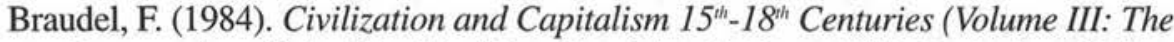
Perspective of the World). (Translated by S. Reynolds). Berkeley: University of California Press.

Chang, Y.-T. (2003). "Korea's Strategic Plan to be Northeast Asia's Logistics Hub: Towards the Pentaport Approach," Korea Observer, 34(3): 437-460.

Cheong, S.-M. (2002). "Marine Tourism," Korea Observer, 33(2): 257-266.

Grenier, D., Kaae, B., Miller, M.L., and R.W. Mobley. (1993). "Ecotourism, Landscape Architecture, and Urban Planning," Landscape and Urban Planning. 25: 1-16.

Hershman, M.J. and K.M. Chamberlin. (2003). "Port-City Change and Growth:

Examples from the Pacific Northwest of the US," Korea Observer, 34(3): 485-508.

Hong, J.-S. (1998). Tidal Flats of Korea. [in Korean]. Seoul: Daewonsa Publishing Co.

Inha University. (2003). Proceedings of the Workshop on Strategies for Sustainable

Coastal Development Toward Northeast Asian Hub : Comparison Between Incheon and Seattle Areas. (29-30 April 2003, Sponsored by the Korean Ministry of Maritime Affairs and Fisheries, Incheon Metropolitan City, and the US National Science Foundation; Inha University, Incheon, Korea) Inha University and the University of Washington.

Jun, I.-S. (2003). “An Agenda for the Incheon Free Economic Zone: Developing Quad Ports and Quad Parks," Journal of International Logistics and Trade, 1(1): 85106.

\footnotetext{
${ }^{22}$ Experts could also be recruited from industry and from nongovernmental organizations (NGOs).
} 
Kim, S.-G. and Y.-J. Kim (1996). "Overview of Coastal and Marine Tourism in Korea," The Journal of Tourism Studies, 7(2): 46-53.

Miller, M.L. (1989). “Coastal Tourism Planning,” Oceans '89 (Proceedings of the 1989 Annual Meeting). Piscataway, New Jersey: Institute of Electrical and Electronic Engineers, pp. 112-116.

Miller, M. L. and R. (1986). "Travel, Tourism, and Marine Affairs," Coastal Zone Management Journal 14 (1/2); 1-19.

Miller, M.L., and Auyong, J. 1991. "Coastal Zone Tourism: A Potent Force Affecting Environment and Society”. Marine Policy, 15, 75-99.

Miller, M.L., and Auyong, J., 1998. "Remarks on Tourism Terminologies: Anti-tourism, Mass Tourism, and Alternative Tourism". In: Proceedings of the 1996 World Congress on Coastal and Marine Tourism: Experiences in Management and Development (M. L. Miller and J. Auyong, eds.) Washington Sea Grant Program and the School of Marine Affairs, University of Washington and Oregon Sea Grant College Program, Oregon State University, pp. 1-24.

Miller, M. L., Auyong, J., and N. Hadley. (2002). "Sustainable Coastal Tourism,” In: Proceedings of the 1999 International Symposium on Coastal and Marine Tourism : Balancing Tourism and Conservation. (M. L. Miller, J. Auyong, and N. P. Hadley, eds.) Washington Sea Grant Program and School of Marine Affairs, University of Washington; Oregon Sea Grant College Program, Oregon State University; and Oceans Blue Foundation: Seattle, WA. pp. 3-20.

Miller, M. L. and R. A. Ellis. (2003a). "A Sustainable Coastal Tourism Agenda for the Regions of Incheon and Seattle," In: Proceedings of the Workshop on Strategies for Sustainable Coastal Development Toward Northeast Asian Hub : Comparison Between Incheon and Seattle Areas. (29-30 April 2003, Sponsored by the Korean Ministry of Maritime Affairs and Fisheries, the Metropolitan City of Incheon, and the US National Science Foundation, Inha University, Incheon, Korea) Inha University and the University of Washington. 24 pages.

Miller, M. L. and R. A. Ellis. (2003b). "Coastal Tourism Development in Incheon and Seattle," Korea Observer, 34(3): 509-534.

Reich, R.B. (1991). The Work of Nations: Preparing for the 21 $1^{\text {st }}$ Century. New York: Vintage Press.

Sorensen, C. W. (2003). "Cultural Dimensions of Quality of Life for International Visitors to Korea," Korea Observer, 34(3): 461-484.

Sorensen, C. W. and K. Mallane. (2003). "Researching Perception and Attitude Formation between Koreans and Tourists in Korea," Invited paper in Proceedings of the Pentaport Seminar to Develop Incheon as Logistics Hub in Northeast Asia, (Inha University, 27-29 October).

Urban Development Authority. (2003). Creative City: The Land of OpportunityIncheon. Incheon Metropolitan City: Incheon. 


\section{Additional Supporting References}

Korea National Tourism Organization. (1996-2001). [general statistics].

Korea National Tourism Organization. (1999). Development Plan of the South Coast Tourism Belt. (December).

Korea National Tourism Organization. (1996-2001). Korean Annual Report

Ministry of Marine Affairs and Fisheries [MOMAF]. (2000). Ocean Korea 21: Basic Plan for the Development of Maritime Affairs and Fisheries. (January).

Ministry of Marine Affairs and Fisheries [MOMAF]. (2000). The Long-term Development Plan for Marine Tourism in Korea.

Ministry of Marine Affairs and Fisheries [MOMAF]. (2000). A Study on the Comprehensive Development Plan for the Promotion of Marine Tourism. (April).

Ministry of Marine Affairs and Fisheries [MOMAF]. (2002). A Study on the Obsolete Port Facilities and Restructuring Plan.

Tyrrell, T., Chang, Y.-T., and S.-G. Kim. (1998). "Coastal Tourism Development and EXPO'10 in Korea," Proceedings of the First Annual Korea-US Marine Policy Forum, (October 22-23). Seoul, pp. 2.3.1- 2.3.22).

Tyrrell, T, S., Kim, S.-G., and Y.-T. Chang. (1999). "Marine Resource Development in Korea," Marine Resource Economics, 14: 165-174. 